\title{
Deposition of brown carbon onto snow: changes in snow optical and radiative properties
}

\author{
Nicholas D. Beres ${ }^{1,2,3}$, Deep Sengupta ${ }^{1,2}$, Vera Samburova ${ }^{1}$, Andrey Y. Khlystov ${ }^{1}$, and Hans Moosmüller ${ }^{1}$ \\ ${ }^{1}$ Division of Atmospheric Sciences, Desert Research Institute, Reno, NV, USA \\ ${ }^{2}$ Department of Physics, University of Nevada-Reno, Reno, NV, USA \\ ${ }^{3}$ Aerosol and Environmental Physics, University of Vienna, Vienna, Austria
}

Correspondence: Nicholas D. Beres (nicholas.beres@univie.ac.at)

Received: 25 August 2019 - Discussion started: 23 September 2019

Revised: 3 April 2020 - Accepted: 6 April 2020 - Published: 26 May 2020

\begin{abstract}
Light-absorbing organic carbon aerosol - colloquially known as brown carbon $(\mathrm{BrC})$ - is emitted from combustion processes and has a brownish or yellowish visual appearance, caused by enhanced light absorption at shorter visible and ultraviolet wavelengths $(0.3 \mu \mathrm{m} \lesssim \lambda \lesssim 0.5 \mu \mathrm{m})$. Recently, optical properties of atmospheric $\mathrm{BrC}$ aerosols have become the topic of intense research, but little is known about how $\mathrm{BrC}$ deposition onto snow surfaces affects the spectral snow albedo, which can alter the resulting radiative forcing and in-snow photochemistry. Wildland fires in close proximity to the cryosphere, such as peatland fires that emit large quantities of $\mathrm{BrC}$, are becoming more common at high latitudes, potentially affecting nearby snow and ice surfaces.

In this study, we describe the artificial deposition of $\mathrm{BrC}$ aerosol with known optical, chemical, and physical properties onto the snow surface, and we monitor its spectral radiative impact and compare it directly to modeled values. First, using small-scale combustion of Alaskan peat, $\mathrm{BrC}$ aerosols were artificially deposited onto the snow surface. UV-Vis absorbance and total organic carbon (TOC) concentration of snow samples were measured for samples with and without artificial $\mathrm{BrC}$ deposition. These measurements were used to first derive a $\mathrm{BrC}$ (mass) specific absorption $\left(\mathrm{m}^{2} \mathrm{~g}^{-1}\right)$ across the UV-Vis spectral range. We then estimate the imaginary part of the refractive index of deposited $\mathrm{BrC}$ aerosol using a volume mixing rule. Single-particle optical properties were calculated using Mie theory, and these values were used to show that the measured spectral snow albedo of snow with deposited $\mathrm{BrC}$ was in general agreement with modeled spectral snow albedo using calculated $\mathrm{BrC}$ optical properties. The instantaneous radiative forcing per unit mass of to-
\end{abstract}

tal organic carbon deposited to the ambient snowpack was found to be $1.23(+0.14 /-0.11) \mathrm{W} \mathrm{m}^{-2}$ per part per million (ppm). We estimate the same deposition onto a pure snowpack without light-absorbing impurities would have resulted in an instantaneous radiative forcing per unit mass of 2.68 $(+0.27 /-0.22) \mathrm{W} \mathrm{m}^{-2}$ per ppm of $\mathrm{BrC}$ deposited.

\section{Introduction}

Aerosol light absorption in the Earth's atmosphere lowers the planetary albedo, thereby causing radiative heating (Moosmüller et al., 2009; Satheesh and Krishna Moorthy, 2005; Stier et al., 2007; Stocker et al., 2013). Aerosols with a zero or very large imaginary part of their refractive index do not absorb light (Moosmüller and Sorensen, 2018a, b, 2019; Sorensen et al., 2019). However, with the exception of metals, all atmospheric aerosols with a nonzero imaginary part of their refractive index do contribute to atmospheric light absorption. This absorption is distinct from other radiative forcing mechanisms such as aerosol scattering because light-absorbing aerosols continue to substantially contribute to radiative forcing after deposition onto high albedo surfaces such as snow and ice (Skiles and Painter, 2018; Warren, 1982). They contribute to climate forcing (Hansen and Nazarenko, 2004; Jacobson, 2004) by significantly lowering snow and ice albedo (Chýlek et al., 1983; McConnell et al., 2007; Warren and Wiscombe, 1980), thereby reducing snow cover duration and changing spring runoff timing (Déry and Brown, 2007; Painter et al., 2007; Strack et al., 2007). Most previous work discusses reduction of snow 
albedo due to deposited black carbon (BC) and mineral dust, but little is known about snow albedo reduction due to deposited brown carbon $(\mathrm{BrC})$. The light-absorbing properties of $\mathrm{BrC}$ - an optically defined component of organic carbon $(\mathrm{OC})$ aerosol - in the cryosphere is a growing topic of research. One source of atmospheric $\mathrm{BrC}$ is smoldering biomass combustion, which is becoming more common at high latitudes as peatlands increasingly dry out and become available as fuel for smoldering wildland fires (Brown et al., 2015; Kohlenberg et al., 2018; Turquety et al., 2007). Primary $\mathrm{BrC}$ aerosol deposition onto snow and ice is of particular concern in northern latitudes, due to the proximity of peat fuels to snow and ice surfaces (e.g., Evangeliou et al., 2019).

\subsection{Brown carbon aerosol}

Both BC and OC aerosols are formed by incomplete combustion of carbon-containing fuels (Andreae and Gelencsér, 2006; Bond et al., 2013), and their contribution to a source's total emissions and their characteristics depends on many factors including fuel type, moisture content, packing density and source depth (Sumlin et al., 2018b), combustion phase (Bond et al., 2004; Patterson and McMahon, 1984; Reid et al., 2005), and other elements of the system (Chen et al., 2006). Many studies have focused on the light absorption of the water-soluble fraction of OC, particularly that of humic-like substances (HULIS) (Dang and Hegg, 2014; Graber and Rudich, 2006; Samburova et al., 2005; Sun et al., 2007). In addition, some recent work has focused on the light-absorption characteristics of non-water-soluble polycyclic aromatic hydrocarbons (PAHs) (Samburova et al., 2016) and other compounds derived from extractions with solvents of different polarity and $\mathrm{pH}$ (Sengupta et al., 2018).

OC compounds that are absorbing in the ultraviolet (UV) and short-visible wavelengths are colloquially known as $\mathrm{BrC}$. The wavelength dependency of $\mathrm{BrC}$ aerosol absorption coefficients can be described by an absorption Ångström exponent (AAE) that is significantly greater than one (Chakrabarty et al., 2010; Corr et al., 2012; Kirchstetter et al., 2004; McNaughton et al., 2011; Moosmüller et al., 2011), whereas BC aerosol absorption coefficients are less wavelength-dependent (i.e., $\mathrm{AAE} \approx 1$ ) over the visible range and its periphery (Bergstrom et al., 2007; Moosmüller et al., 2009). The optical properties of $\mathrm{BrC}$ are described by the wavelength-dependent $\mathrm{BrC}$ complex refractive index $m_{\lambda}$ written as

$m_{\lambda}=n_{\lambda}+i \kappa_{\lambda}$,

where $n_{\lambda}$ is the real part and $\kappa_{\lambda}$ is the imaginary part of the refractive index, the latter of which provides the primary control of the absorption coefficient (Sorensen et al., 2019). The imaginary part of the $\mathrm{BrC}$ refractive index (i.e., $\kappa_{\lambda}$ ) increases greatly toward shorter wavelengths in the visible and near-UV spectrum, giving $\mathrm{BrC}$ its colored appearance and namesake (Andreae and Gelencsér, 2006). BrC aerosol op- tical properties are determined both by $\mathrm{BrC}$ bulk properties discussed above and by particle size distribution and morphology. As BrC particles from smoldering combustion are mostly homogeneous (Sumlin et al., 2018a) and spherical (Chakrabarty et al., 2010), BrC aerosol optics can be described by the $\mathrm{BrC}$ complex refractive index and size distribution using Mie theory (Mie, 1908; Moosmüller et al., 2011; Sumlin et al., 2018b).

A variety of fuels emit $\mathrm{BrC}$ during open combustion (Laskin et al., 2015), but peat is of particular interest for its common physical proximity to snow and ice at high latitudes of the Northern Hemisphere (Joosten and Clarke, 2002) and due to its strong tendency to burn in the smoldering combustion phase (Watts and Kobziar, 2013). Peatlands are a land surface primarily found in the Northern Hemisphere composed of organic soil and decomposing plant material. They make up a small fraction $(\sim 2 \%-3 \%)$ of Earth's land surface but store a significant amount $(\sim 25 \%)$ of the world's soil organic carbon (Turetsky et al., 2014; Xu et al., 2018). Under a warming climate, by the end of the 21 st century, a doubling of boreal area burned per year has been predicted (Flannigan et al., 2009; Oris et al., 2014). Increases in boreal peatland fires will cause increased emissions of $\mathrm{OC}$ and $\mathrm{BrC}$ aerosols at high latitudes.

Approximately $88 \%$ of all carbonaceous aerosol mass emitted globally is from wildland fires and biomass fuel combustion (Bond et al., 2004), and approximately $80 \%$ of those emissions are from smoldering combustion phase fires (Einfeld et al., 1991). OC is emitted together with BC from combustion sources, but more so in the smoldering phase (Bond et al., 2004; Patterson and McMahon, 1984; Reid et al., 2005), and it differs significantly in optical and chemical properties (Bond et al., 2013; Chakrabarty et al., 2016; Kirchstetter et al., 2004; Laskin et al., 2015; Lewis et al., 2008; Moosmüller et al., 2009).

Carbonaceous particles also often undergo continued, secondary changes - physically, chemically, and optically - during transport within the atmosphere (Bhattarai et al., 2018; Jimenez et al., 2009; Sengupta et al., 2018; Sumlin et al., 2017). Chemical transformation of $\mathrm{BrC}$ during atmospheric transport can involve either fragmentation processes, producing lower-molecular-weight compounds (Ervens et al., 2004), or oligomerization (Carlton et al., 2007).

\subsection{Brown carbon in the cryosphere}

OC from both natural and anthropogenic sources can be deposited onto snow after transport. The presence of OC in snow and ice not only plays a critical role in the carbon cycle of the cryosphere and of waterways downstream of snowmelt, but also contributes to the darkening of the snow surface at the short-visible and UV wavelengths. While studies of impurities in snow and their reduction of snow albedo have focused on light absorption by BC and/or mineral dust (Qian et al., 2015; Skiles et al., 2018), these impurities alone 
may not explain the decreased albedo at short-visible and UV wavelengths in the cryosphere.

Although only a small fraction of the total incoming solar irradiance at the snow surface is in the UV, it is a major driver of snow photochemistry that can be altered by $\mathrm{BrC}$ deposition near the top of the snowpack. Snow photochemistry includes nitrate and nitrite photolysis, which releases $\mathrm{NO}_{x}$ back into the atmosphere (Domine et al., 2008; Honrath et al., 1999, 2000), and mercury and bromine chemistry (Fain et al., 2006; Grannas et al., 2007). Additionally, biota in the cryosphere, such as snow algae (e.g., Chlamydomonas nivalis) (Thomas and Duval, 1995; Yallop et al., 2012), depend on incident light, and deposited impurities, such as $\mathrm{BrC}$, can alter this interaction by absorbing light.

The influence of deposited $\mathrm{BrC}$ aerosols on surface and in-snow radiative properties is a recent and emerging topic. Grannas et al. (2007) provided an excellent overview of reactive organic compounds in snow and their impact on photolysis on and within the snow, but the direct impact of $\mathrm{BrC}$ on increased absorption and subsequent albedo effects was not addressed. Doherty et al. (2010) discovered the widespread presence of non-BC absorbing impurities (including $\sim 25 \%-50 \%$ contribution to total light absorption by $\mathrm{BrC}$ ) throughout the Arctic, but the spectral albedo of these non-BC constituents was not reported. Similarly, Lin et al. (2014) extensively modeled the impact of $\mathrm{BrC}$ and other organic aerosols on global radiative forcing estimates. Wu et al. (2016) provided a nice but brief overview of $\mathrm{BrC}$ in the cryosphere and estimated effects on snow radiative forcing. One issue affecting advances in understanding the roles that $\mathrm{BC}$ and non-BC aerosols play for radiative forcing in and on snow is that partitioning their influence is difficult. Dang and Hegg (2014) described an extensive investigation identifying the absorbing components of non-BC materials - likely including $\mathrm{BrC}$ - in snow from across the western United States using chemical extraction methods. For example, extraction of aerosols collected on filters allows for the separation of $\mathrm{BC}$ and non-BC constituents, but temporal resolution is lost when compared to real-time measurement methods.

Deposition of $\mathrm{BrC}$ onto and into snow and its radiative effects can be studied in detail and at sufficiently high BrC concentrations by artificially depositing $\mathrm{BrC}$ onto the snow surface (Beres and Moosmüller, 2018). Such experiments can deposit BrC aerosol onto snow - from fuel sources that are likely to exist near snow surfaces, such as peat - and quantify changes in snow composition (e.g., OC concentration) and radiative properties (e.g., spectral albedo). Here, we describe artificial deposition experiments, performed on natural snow surfaces in the Sierra Nevada, USA, and report changes in snow OC content, meltwater absorption spectra, measured and modeled snow spectral albedos, and resulting radiative forcing due to the presence of impurities both naturally occurring and artificially deposited.

\section{Methods}

\subsection{Study area and field work}

An overview of methods used for this work is presented in Fig. 1 as a guide to the relationships between measurements and modeling presented in the following sections. Experiments for this study were conducted at a small, alpine lake, Tamarack Lake (2694 ma.s.l.), in the Carson Range of the Sierra Nevada in Nevada, USA. Depositions for this study took place during the winter/spring season of 2018-2019. Near the experiment site is a well-traveled mountain highway over Mount Rose pass, a ski resort, and the city of Reno, Nevada, USA. Sources of snow contamination include vehicle emissions along that highway, regional anthropogenic and biogenic sources in the Lake Tahoe region (Green et al., 2012; McDaniel and Zielinska, 2015), and long-range transport from California and Asia (Hadley et al., 2010). While our study site is not free from influences of natural and anthropogenic sources, it provides a flat, easy-to-access, untrodden snow field, ideal for experiments involving the artificial deposition of aerosols. Experiments were conducted on a clear-sky, windless day.

Field experiments were conducted in the following order: (1) begin combustion of fuel to generate aerosols for deposition; (2) during deposition of aerosols ( $\sim 40 \mathrm{~min}$ ), excavate abbreviated snow pit upwind of deposition, measure snow density, and collect snow samples of natural snowpack; (3) upon completion of aerosol deposition, immediately remove deposition apparatus and measure spectral albedo over the deposition area; (4) measure spectral albedo of natural snowpack several meters upwind of deposition area; and (5) excavate snow pit at deposition site and collect snow samples. A second deposition experiment was conducted on the same day, and steps (1)-(5) were repeated and results included in this study.

Aerosol depositions onto the snow were made using the apparatus previously described by Beres and Moosmüller (2018). Briefly, combustion aerosols are produced and deposited onto and into the snowpack by means of two near-cylindrical volumes. The first acts as an aerosol production chamber, where small-scale combustion of fuels produces aerosols in situ. Using an external, battery-powered pump, aerosols are pumped from the first to a second, larger volume that is placed over the snow surface where deposition is desired. Prior to combustion, the fuels are placed into a round, insulated container (volume of this container is $\sim 1610 \mathrm{~cm}^{3}$ ) to mimic real-world conditions in which surrounding, unburned peat provides insulation for the smoldering biomass, similar to the methods of Chakrabarty et al. (2016), Sengupta et al. (2018), and Sumlin et al. (2017, $2018 \mathrm{a}, \mathrm{b})$. The fuels burned mostly with lower-temperature, smoldering-phase combustion producing OC-rich biomassburning aerosols, where any visible flaming combustion was quickly extinguished to ensure $\mathrm{OC}$ to $\mathrm{BC}$ emission ratios are 


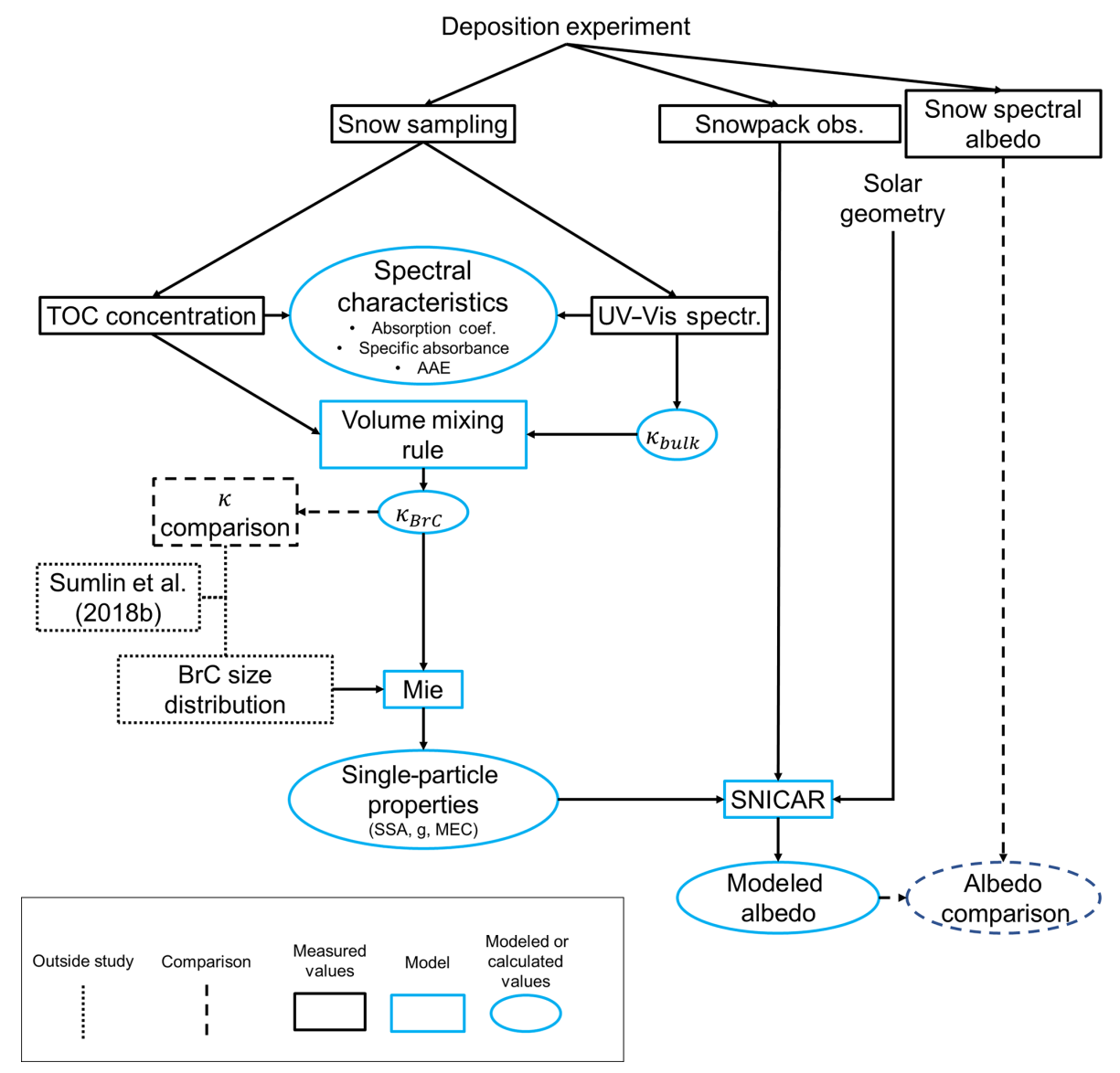

Figure 1. Overview of methods used to derive $\mathrm{BrC}$ optical properties and compare measured and modeled albedo. The Sengupta et al. (2018) and Sumlin et al. (2018b) studies both provide previously derived values of $\kappa_{\mathrm{BrC}}$ to compare, and Sumlin et al. (2018b) provide a size distribution of $\mathrm{BrC}$ aerosol under similar combustion conditions to those used in this study.

high (Chakrabarty et al., 2016). Fuels burned for approximately $40 \mathrm{~min}$, with air from the combustion volume being pumped into the deposition volume for an additional $10 \mathrm{~min}$ after the end of fuel combustion to encourage deposition of aerosols remaining in the volume. After this, the deposition volume was removed, and the experiment continued. The areal extent of deposited aerosol is approximately $0.20 \mathrm{~m}^{2}$.

The fuel combusted for $\mathrm{BrC}$ aerosol deposition consisted of boreal peat samples collected from interior Alaska (hereafter "AK peat" or "AKP" in figures). Details of the fuel collection and preparation can be found in the Supplement of Chakrabarty et al. (2016). The properties of this fuel's combustion emissions have been extensively studied under similar combustion conditions for their impact on air quality and radiative forcing in the atmosphere through optical, physical, and chemical characterization (Chakrabarty et al., 2016; Samburova et al., 2016; Sengupta et al., 2018; Sumlin et al., 2017, 2018a, b). Peat fuels were harvested and stored under refrigeration after collection. A few days before snow deposition fieldwork, these fuels were conditioned in a heating and drying oven (Fisherbrand Isotemp, Waltham, MA) at a tem- perature of $\sim 90^{\circ} \mathrm{C}$ for $1 \mathrm{~d}$ in order to remove fuel moisture. Dried peat samples were weighed, and deionized water was sprayed homogeneously on those dry samples until the total mass of the wet peat samples showed a $25 \%$ increase compared to dried peat sample mass (i.e., fuel moisture content of $25 \%$ ). Prior to their use in field combustion experiments, the wet peat samples remained for $1 \mathrm{~d}$ of equilibration in Uline static-shielding Ziploc bags.

Spectral albedo measurements of natural and aerosoldeposited snow surfaces were made using a fiber-coupled, high-resolution spectroradiometer (FieldSpec3, Analytical Spectral Devices, Inc., Boulder, CO, USA). This instrument measures over a wavelength range of 350-2500 $\mathrm{nm}$ with fullwidth-at-half-maximum bandwidths of $3 \mathrm{~nm}$ (at $700 \mathrm{~nm}$ ) to $10 \mathrm{~nm}$ (at 1400 and $2100 \mathrm{~nm}$ ). Raw spectra are resampled and splined at $1 \mathrm{~nm}$ spectral resolution. Albedo was measured using a cosine-weighted optical diffuser at the fiberend, mounted to a tripod for consistency of measurement location and angle. Reported albedo for this study is the ratio of the average of 10 down-looking (upwelling radiation) measurements to the average of 10 up-looking (downwelling 
radiation) measurements. We limit the reported albedo to the wavelength range of $350-1800 \mathrm{~nm}$, due to noise being introduced further in the near-infrared (NIR) region as well as the fact that aerosol absorption in snow mostly affects the UV and visible wavelength albedo (Skiles et al., 2018; Warren and Wiscombe, 1980), which is the focus of this study. Spectral albedo of the deposited area was measured immediately after the deposition experiment, and spectra of an adjacent, undisturbed snowfield were collected immediately after that.

Snow samples were collected at each deposition area as well as at an upwind area to provide a background for $\mathrm{OC}$ and other impurities present in the natural snowpack. First, samples were collected in an area of undisturbed natural snow and later directly below the center of the deposition area at three depth ranges to gauge the depth at which $\mathrm{BrC}$ penetrated into the snowpack: surface $(0 \mathrm{~cm})$ to $2.5 \mathrm{~cm}$ (referred to herein as L1), 2.5 to $7.5 \mathrm{~cm}$ (L2), and 7.5 to $12.5 \mathrm{~cm}$ below the surface (L3) (Fig. 2). Each snow sample was placed into a polyethylene sampling bag (e.g., Whirl-Pak) and kept frozen in a freezer at $-20^{\circ} \mathrm{C}$ to prevent melting and minimize scavenging of OC.

\subsection{Laboratory measurements}

Light-absorbing impurities in snow include BC, mineral dust, and OC compounds; they are commonly quantified with optical methods (Cereceda-Balic et al., 2019; Grenfell et al., 2011; Skiles et al., 2017), X-ray fluorescence (Moosmüller et al., 2012), and chemical oxidation (Godec et al., 1990), respectively. Here, snow samples were processed to quantify total organic carbon (TOC) concentration using a total carbon analyzer and absorbance using a laboratory spectrophotometer at the Desert Research Institute (DRI) in Reno, NV, USA. For analysis, snow was transferred into $50 \mathrm{~mL}$ volume polypropylene vials that were first presoaked in $18.2 \mathrm{M} \Omega$ ultrapure water (UPW, model Purelab Ultra, Elga Labwater, Paris, France) for over $48 \mathrm{~h}$ and then thrice rinsed using UPW. Snow was allowed to melt at room temperature $\left(\sim 21^{\circ} \mathrm{C}\right.$ ) to discourage the volatilization of organics (as may occur when melting with a microwave or other accelerated means) and then immediately analyzed for TOC.

TOC was measured using a total carbon analyzer (Sievers 900 Series, SUEZ, San Jose, CA, USA). This instrument measures total carbon (TC) and inorganic carbon (IC) concentrations and infers TOC as the difference of these two (i.e., TOC $=$ TC-IC). The instrument photochemically oxidizes organic compounds in a liquid sample through chemical oxidation with ammonium persulfate and reactions with hydroxyl radicals produced through the photolysis of water under UV irradiance. Within the instrument, the sample stream is split in two, where one analysis path (for IC) determines the $\mathrm{CO}_{2}$ formed through interaction with the ammonium persulfate only, and the other path (for TC) determines the $\mathrm{CO}_{2}$ produced through both ammonium persulfate and UV-induced oxidation (TC). Then, the $\mathrm{CO}_{2}$ in the sample stream is measured through a patented conductivity detector. The instrument has a reported lower detection limit of $0.03 \mathrm{ppb}$ (part per billion) TOC and accuracy of $\pm 2 \%$ or $\pm 0.5 \mathrm{ppb}$, whichever is greater. TOC concentrations are reported as volume fractions (ppb) by the instrument but will be reported as OC mass concentrations herein (ppm $=\mathrm{mg} \mathrm{L}^{-1}=\mathrm{g} \mathrm{m}^{-3}$ ) unless otherwise stated. According to the instrument manufacturer, a $60 \mu \mathrm{m}$ stainless-steel inline filter is used to restrict very large plant detritus, insects, etc. from passing through the sample inlet line into the instrument. Because surface snow spectral albedo was measured with all particles present before and after the deposition experiments, the snow meltwater samples were not filtered prior to TOC determination and therefore may contain particulate and nonparticulate $\mathrm{OC}$, as well as water-soluble and insoluble $\mathrm{OC}$ compounds. $\mathrm{BrC}$ aerosols generated through similar small-scale smoldering combustion experiments generally do not exceed $1 \mu \mathrm{m}$ in diameter and have a geometric mean diameter close to $100 \mathrm{~nm}$ (Chakrabarty et al., 2016; Sumlin et al., 2017, 2018b) and therefore are included in the measured TOC concentration. Contribution of the WhirlPak bags to measured TOC concentration is nonzero, even for samples that remain frozen (Legrand et al., 2013); however, we expect these discrepancies to mostly subtract out between deposited and natural snow samples. Contamination of the polypropylene vials with TOC was measured to be $0.020 \pm 0.001 \mathrm{~g} \mathrm{~m}^{-3}$, which was subtracted from each of the meltwater TOC measurements. To the best of the authors' knowledge, the Sievers TOC analyzer and its methods to oxidize organic compounds in liquid samples is unable to convert any $\mathrm{BC}$ present to $\mathrm{CO}_{2}$, as $\mathrm{BC}$ is chemically inert and resistant to oxidation (Bond and Bergstrom, 2006), especially under the limited exposure that the instrument subjects the sample to $(\sim 4 \mathrm{~min})$.

For this study, we assume that while the natural snowpack contributes to the measured TOC, it is free from influence of the aerosol deposition experiment. We can thus infer the background TOC concentration of both the natural snowpack located at the Tamarack Lake site as well as the direct TOC contribution of the $\mathrm{BrC}$ aerosol deposition experiment. That is, the $\mathrm{OC}$ added to the snowpack through the deposition experiment $\mathrm{TOC}_{\mathrm{BrC}, i}$ can be calculated for layer $i$ as

$\mathrm{TOC}_{\mathrm{BrC}, i}=\mathrm{TOC}_{\text {bulk }, i}-\mathrm{TOC}_{\text {snow }, i}$,

where $\mathrm{TOC}_{\text {bulk }}$ is the measured TOC from the deposition site samples that include both OC already in the natural snowpack and artificially deposited $\mathrm{OC}$, and $\mathrm{TOC}_{\text {snow }}$ is the measured TOC from the natural snowpack. The uncertainties presented in this study for TOC concentrations represent the standard deviation of the mean for all $n$ individual TOC determinations $(13 \leq n \leq 72)$ and $N$ replicate meltwater TOC measurements $(2 \leq N \leq 4)$.

Light absorbance of the melted snow was measured using a PerkinElmer Lambda 1050 UV/Vis spectrophotometer (Waltham, MA, USA). Prior to measurement, the melted 


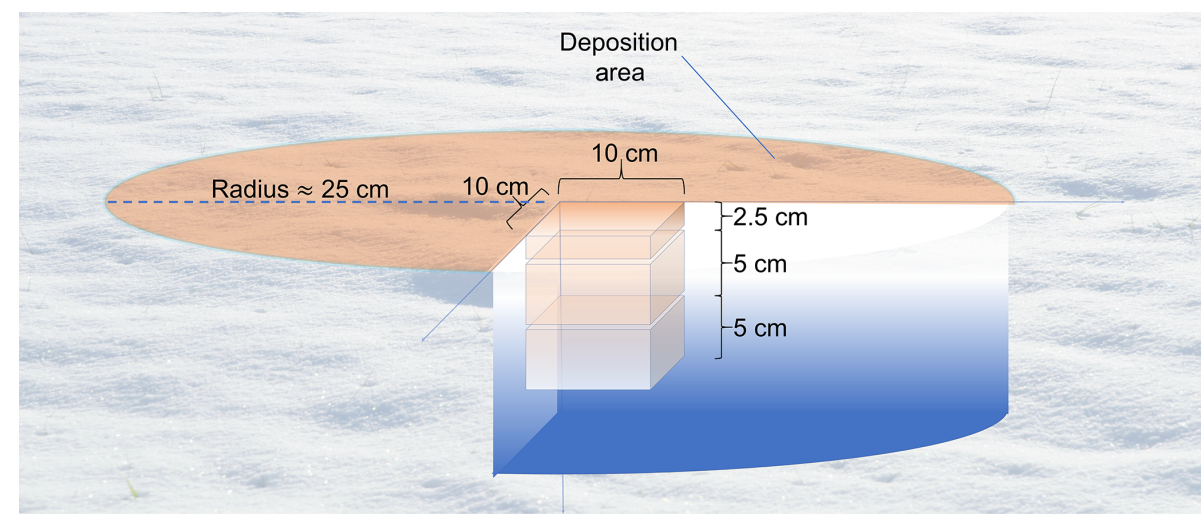

Figure 2. Samples for analysis are collected in three vertical layers. For the deposition area, as depicted here, samples are taken from the center of the area. Samples to represent the natural snowpack are collected similarly upwind of the deposition to minimize contamination. Note: lengths are not to scale.

snow samples were sonicated for $\sim 20 \mathrm{~min}$ and stirred to ensure the solubility of water-soluble organic compounds (WSOCs). However, uniformity of suspended particles cannot be controlled through sonication. Sonicated meltwater samples were placed into a $1 \mathrm{~cm}$ path length cuvette. To avoid potential contaminations between samples, this cuvette was flushed with methanol and rinsed several times with UPW. Measurement scans were performed for each sample over the $200-860 \mathrm{~nm}$ wavelength range with $1 \mathrm{~nm}$ resolution and with UPW serving as reference. The instrument reports the absorbance $A$ as the power exponent of the Beer-Lambert law, where the transmittance, $T$, of light through a solution is a ratio of the radiant flux transmitted $\Phi_{e}^{\mathrm{t}}$ to the total radiant flux incident $\Phi_{e}^{\mathrm{i}}$ on the sample. This method assumes there is little contribution of scattering to the overall extinction of light along the path (Bosch et al., 2014). This is appropriate for a suspension or solution where extinction is dominated by absorption caused by dissolved OC and/or by carbonaceous particles smaller than the wavelength of incident light, where extinction due to scattering can be neglected. Transmittance $T$ is related to absorbance $A$ as

$T=\frac{\Phi_{e}^{\mathrm{t}}}{\Phi_{e}^{\mathrm{i}}}=10^{-A}=e^{-\tau}$

and absorbance $A$ is related to optical depth $\tau$ by

$A=\frac{\tau}{\ln 10}$.

If the optical attenuation is uniform along the path of light, the absorption coefficient $\beta_{\text {abs }}$ is related to the optical depth $\tau$ in Eq. (4) as

$\tau=l \cdot \beta_{\mathrm{abs}}$,

where $l$ is the path length of light through the liquid sample. For absorbance spectra, we consider the bulk matter of melted pure ice grains and the impurities that lie both internal and external to the grain matrix and evaluate them as a bulk sample. The bulk absorption coefficient $\beta_{\text {abs_bulk }}$ is directly related to the imaginary refractive index $\kappa_{\text {bulk }}$ (Moosmüller et al., 2009) as

$\beta_{\text {abs_bulk }}=\frac{4 \cdot \pi \cdot \kappa_{\text {bulk }}}{\lambda} ;$

so, the estimation of $\kappa_{\text {bulk }}$ follows as

$\kappa_{\text {bulk }}=\frac{\ln (10) \cdot \lambda \cdot A}{4 \cdot \pi \cdot l}$.

The raw absorbance measurements were baseline-corrected to account for instrumental drift by subtracting the scan average over the $700-860 \mathrm{~nm}$ wavelength range from individual wavelength absorbance values, similar to the method outlined by Sengupta et al. (2018). In addition, this reduces some influence of $\mathrm{BC}$ particle light absorption across the $\mathrm{UV}-\mathrm{Vis}$ spectrum, while only minimally affecting $\mathrm{BrC}$ particle absorption that is much greater at blue and near-UV wavelengths (Bahadur et al., 2012; Chakrabarty et al., 2010; Kirchstetter and Thatcher, 2012; Lu et al., 2015; Sumlin et al., 2018b). Additionally, each spectrum was smoothed using a running average of 15 spectral data points to reduce highfrequency noise while maintaining low-frequency structure.

Similar to measurements of TOC, we consider the bulk snow-aerosol sample when estimating a value for $\kappa$-both for the natural snowpack including its naturally occurring impurities $\left(\kappa_{\text {snow }}\right)$ and for the BrC-aerosol-deposited snow $\left(\kappa_{\text {bulk }}\right)$ - as determined through spectrophotometric absorbance measurements. We can isolate the influence of $\mathrm{BrC}$ absorption (via the imaginary refractive index) by incorporating the TOC concentration through a simple volume mixing approximation (Chýlek et al., 1988) as

$\kappa_{\text {bulk }, i}=\kappa_{\mathrm{BrC}, i} \cdot \mathrm{VF}_{\mathrm{BrC}, i}+\kappa_{\text {snow }, i} \cdot \mathrm{VF}_{\text {snow }, i}$,

where $\mathrm{VF}_{\mathrm{BrC}}$ and $\mathrm{VF}_{\text {snow }}$ are the volume fractions of $\mathrm{BrC}$ and bulk meltwater TOC, respectively, for each layer $i$, such that 
$\mathrm{VF}_{\mathrm{BrC}}+\mathrm{VF}_{\text {snow }}=1$. Because the absorbance measurements are made against UPW, we do not include $\kappa$ or the volume fraction of UPW in Eq. (8). Therefore, the average imaginary part of the refractive index of $\mathrm{BrC}$, here labeled as $\kappa_{\mathrm{BrC}, i}$ for each layer $i$, can be written as

$\kappa_{\mathrm{BrC}, i}=\frac{\kappa_{\text {bulk }, i}-\left(\kappa_{\text {snow }, i} \cdot \mathrm{VF}_{\text {snow }, i}\right)}{\mathrm{VF}_{\mathrm{BrC}, i}}$.

Because two samples of the natural snowpack at Tamarack Lake were collected on the same day, we average values of TOC and absorbance over these two natural snowpack samples for each layer. Henceforth, the natural snowpack will be presented as one set of three depths/layers unless otherwise stated.

\section{Results and discussion}

Aerosol deposition experiments were conducted during April 2019. Two separate depositions of $\mathrm{BrC}$ aerosols produced from the smoldering combustion of AK peat were performed (Experiment 1 and 2), and the analysis of the snow properties and spectral albedo from the field and laboratory and modeling results are discussed below.

\subsection{Field work}

Two aerosol depositions were performed on 24 April 2019 (approximately 2 weeks after the last snowfall) at Tamarack Lake. Snowpack and experimental conditions are presented in Table 1 . The average snowpack depth measured on 24 April 2019 at Tamarack Lake was $180 \mathrm{~cm}$. Liquid water was noted in approximately the top $1 \mathrm{~cm}$ of snow, but snow below the surface did not contain liquid water.

The first and second deposition included aerosol generation through smoldering combustion for 40 and $37 \mathrm{~min}$, respectively, followed by $10 \mathrm{~min}$ of residual aerosol deposition. At the start of the experiments, the wet fuel mass was 55 and $45 \mathrm{~g}$ for first and second deposition, respectively. The fuel packing density for both burns was $\sim 0.03 \mathrm{~g} \mathrm{~cm}^{-3}$, which is considered to be a low fuel packing density (Sumlin et al., 2018b).

Similar to the $\mathrm{BrC}$ aerosol deposition experiment previously discussed by Beres and Moosmüller (2018), deposited $\mathrm{BrC}$ aerosol from the smoldering combustion of AK peat appeared yellowish to the eye, indicating a preferential light absorption of blue-violet wavelengths by the aerosol deposited. This strong wavelength dependence was quantified by the measured spectral albedo for each deposition experiment, which is shown in Fig. 3 alongside the measured albedo of the natural snowpack upwind of the deposition. Spectral albedo reduction due to the presence of freshly deposited $\mathrm{BrC}$ aerosol increased with decreasing wavelength in the UV-visible wavelength region for both deposition experiments. In the UV, there was a stronger reduction in albedo than in the visible, of $\sim 0.14$ and $\sim 0.21$ at $350 \mathrm{~nm}$ for Experiment 1 and 2, respectively, relative to the natural snowpack albedo (Fig. 3). At $700 \mathrm{~nm}$, however, albedo for each deposition was reduced by less than 0.01 , indicating very little BC added to the snowpack through the deposition experiments. Both depositions reduced the spectral albedo in the measured NIR region as well, and we hypothesize that the reduction of spectral albedo in the NIR is not due to the $\mathrm{BrC}$ or $\mathrm{BC}$ deposited but may be due to the deposition volume enclosing the snowpack and increasing temperature and accelerating metamorphism of the snow grains to larger grain sizes (Davis et al., 1993; Doherty et al., 2013), and thus increasing absorption in that spectral region (Dozier and Painter, 2004; Warren, 1982; Wiscombe and Warren, 1980). At $1030 \mathrm{~nm}$, the albedo was reduced by 0.029 and 0.022 for the first and second experiments, respectively. Using the SNow, ICe, and Aerosol Radiation (SNICAR) model (see Sect. 3.2.2 and Flanner et al., 2007) to estimate effective grain radii by fitting modeled and measured albedos at that wavelength resulted in an increase in grain size from $\sim 682$ to $\sim 807$ and $\sim 605$ to $\sim 695 \mu \mathrm{m}$ for the deposition Experiment 1 and 2, respectively.

The Sierra Nevada snowpack generally receives sufficient $\mathrm{BC}$ and other light-absorbing aerosols to affect the energy balance in an appreciable manner (Dang and Hegg, 2014; Hadley et al., 2010; Sterle et al., 2013). The albedo of the natural snowpack measured during this study indicates the presence of absorbing impurities without artificial deposition of BrC: a hypothetical pure snow spectral albedo - holding other input parameters constant, modeled through SNICAR - would have an albedo near 0.98 at $350 \mathrm{~nm}$. However, measured albedos at $350 \mathrm{~nm}$ for the natural snowpack are appreciably lower, near $\sim 0.84$. Along with $\mathrm{BrC}$ already present in the snow, other impurities are likely a mix of mineral dust and BC (Hadley et al., 2010; Sterle et al., 2013); however, it is $\mathrm{BrC}$ and mineral dust that are responsible for greater albedo decreases (compared to pure snow) at these lower wavelengths (Laskin et al., 2015; Lu et al., 2015; Moosmüller et al., 2009; Skiles et al., 2017; Warren et al., 2019; Wu et al., 2016). While we can account for the presence of $\mathrm{BrC}$ already in the snowpack by assigning the laboratorymeasured UV-Vis absorption to the measured TOC concentrations of the natural snowpack samples, dust concentrations were not measured and therefore remain unknown. However, they are subtracted out in our quantification of the imaginary part of the deposited $\mathrm{BrC}$ refractive index $\left(\kappa_{\mathrm{BrC}}\right)$ because we consider only the difference between natural snow with and without artificial deposition of $\mathrm{BrC}$.

\subsection{Analysis of snow samples}

TOC concentrations in the snowpack before and after deposition are presented in Table 2. Averaging samples collected at both natural snow sampling sites, the L1 TOC concentration was $0.579 \pm 0.014 \mathrm{~g} \mathrm{~m}^{-3}$, for L2 it was $0.436 \pm 0.048 \mathrm{~g} \mathrm{~m}^{-3}$, 
Table 1. Snowpack observations and spectral albedo properties.

\begin{tabular}{|c|c|c|c|c|c|}
\hline Site & $\begin{array}{l}\text { Snow layer (cm } \\
\text { below surface) }\end{array}$ & $\begin{array}{c}\text { Density } \\
\left(\mathrm{kg} \mathrm{m}^{-3}\right)\end{array}$ & $\begin{array}{l}\text { Surface eff. grain radii }{ }^{\mathrm{a}} \\
\qquad(\mu \mathrm{m})\end{array}$ & $\begin{array}{l}\mathrm{SZ}^{\mathrm{b}} \\
\left({ }^{\circ}\right)\end{array}$ & $\begin{array}{c}\text { Avg. air temp. }{ }^{\mathrm{c}} \\
\left({ }^{\circ} \mathrm{C}\right)\end{array}$ \\
\hline \multirow[t]{3}{*}{ Natural snow 1} & $0-2.5$ & 480 & \multirow[t]{3}{*}{682} & \multirow[t]{3}{*}{39.70} & \multirow[t]{3}{*}{12.2} \\
\hline & $2.5-7.5$ & 400 & & & \\
\hline & $7.5-12.5$ & 410 & & & \\
\hline \multirow[t]{3}{*}{ Natural snow 2} & $0-2.5$ & 480 & \multirow[t]{3}{*}{605} & \multirow[t]{3}{*}{29.28} & \multirow[t]{3}{*}{14.9} \\
\hline & $2.5-7.5$ & 440 & & & \\
\hline & $7.5-12.5$ & 450 & & & \\
\hline \multirow[t]{3}{*}{ Deposition 1} & $0-2.5$ & 480 & \multirow[t]{3}{*}{807} & \multirow[t]{3}{*}{39.87} & \multirow[t]{3}{*}{12.2} \\
\hline & $2.5-7.5$ & 400 & & & \\
\hline & $7.5-12.5$ & 360 & & & \\
\hline \multirow[t]{3}{*}{ Deposition 2} & $0-2.5$ & 480 & \multirow[t]{3}{*}{695} & \multirow[t]{3}{*}{29.37} & \multirow[t]{3}{*}{14.9} \\
\hline & $2.5-7.5$ & 440 & & & \\
\hline & $7.5-12.5$ & 350 & & & \\
\hline
\end{tabular}

${ }^{\text {a }}$ Effective grain radii are estimated for the snow surface using SNICAR by matching the measured albedo at the $1030 \mathrm{~nm}$ ice absorption feature to a modeled albedo at the same wavelength (average of 1025 and $1035 \mathrm{~nm}$ values). ${ }^{\mathrm{b}}$ Solar zenith angle at the time of albedo spectra retrieval. ${ }^{\mathrm{c}}$ Average air temperature during albedo spectra retrieval, as measured from the Mt. Rose SNOTEL site, which lies $0.9 \mathrm{~km}$ southeast at $2683 \mathrm{~m}$ in altitude.
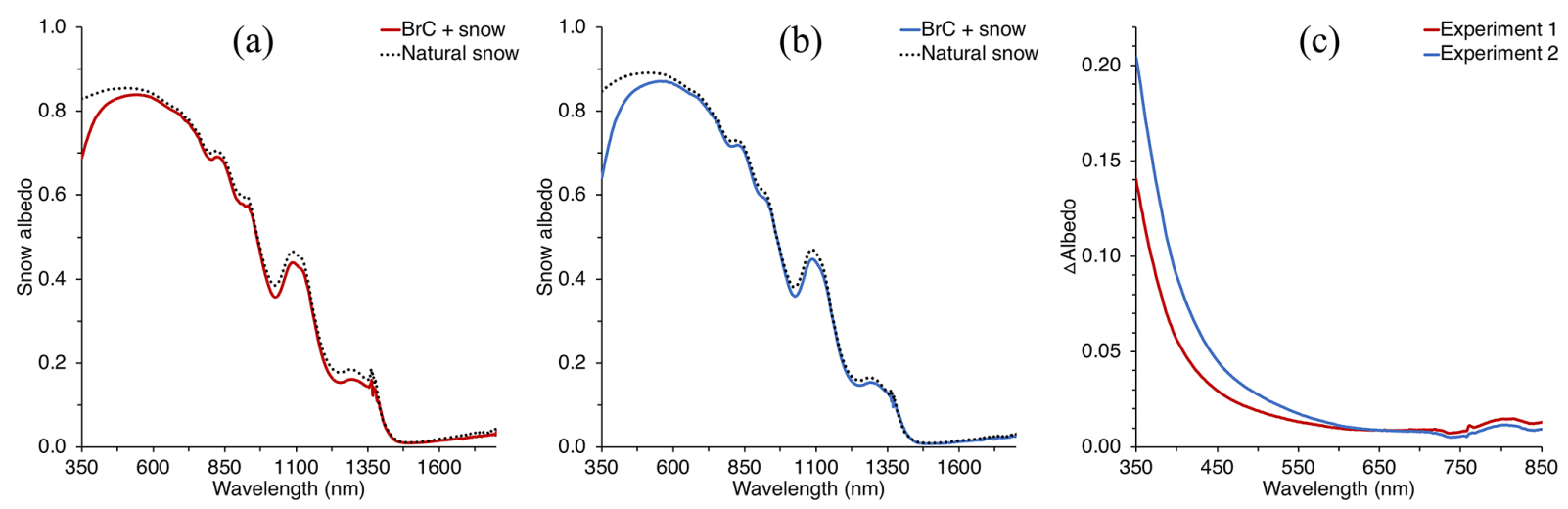

Figure 3. Panels (a) and (b) show the measured spectral snow albedo of the deposition area for Experiment 1 and Experiment 2, respectively, along with an adjacent area of natural snow. Panel (c) indicates the difference between the spectral albedo of the snow with and without deposited $\mathrm{BrC}$ in the UV-Vis wavelength range, indicating a strong wavelength dependence of absorption by impurities deposited on the snow.

and for $\mathrm{L} 3$ it was $0.425 \pm 0.008 \mathrm{~g} \mathrm{~m}^{-3}$. Our OC concentrations fall within the wide range of values found in literature. For example, our concentrations are similar to those reported by Zhang et al. (2019) (and references therein) for OC in snow. Meinander et al. (2013) found a factor of 6 larger, where concentrations are heavily influenced through deposition of air pollution from the mining and refining industry. Legrand et al. (2013) showed that values of OC found in pristine areas of the world are 1 or 2 orders of magnitude lower than our values. The deposition of $\mathrm{BrC}$ aerosol added at least 1 order of magnitude more TOC than was already in the snowpack and increased TOC concentrations below the surface layer as well. Experiment 2 deposited approximately twice the TOC mass concentration as Experiment 1, which is evidenced not only in the measured TOC concentration for each layer, but also in a stronger decrease in measured UV albedo (Fig. 3). Therefore, deposited TOC greatly dominated that already existing in the natural snowpack. While the surface layer (L1) captured a majority of the deposited TOC, the $\mathrm{BrC}$ penetrated deeper into the snowpack during the deposition experiments, either through movement or "pumping" of air into the snow (Colbeck, 1997; Harder et al., 1996; Waddington et al., 1996) or through melt-induced movement of soluble material through the snowpack (Meyer and Wania, 2008, and references therein). The latter may be more likely in a natural scenario of dry deposition (Clifton et al., 2008), although under the conditions of artificial deposition in the winter-spring transition period, the result may be due to both pumping and meltwater flush. 
Table 2. TOC concentrations for the natural snowpack and snow after deposition.

\begin{tabular}{lrrc}
\hline Site & Snow layer $(\mathrm{cm}$ below surface) & TOC $\left(\mathrm{g} \mathrm{m}^{-3}\right)^{\mathrm{a}}$ & TOC uncertainty $\left(\mathrm{g} \mathrm{m}^{-3}\right)^{\mathrm{a}}$ \\
\hline Natural snow 1 & $0-2.5$ & 0.593 & 0.029 \\
& $2.5-7.5$ & 0.388 & 0.018 \\
\hline Natural snow 2 & $7.5-12.5$ & 0.433 & 0.080 \\
\hline Deposition 1 & $0-2.5$ & 0.565 & 0.010 \\
& $2.5-7.5$ & 0.485 & 0.055 \\
& $7.5-12.5$ & 0.417 & 0.014 \\
\hline Deposition 2 & $0-2.5$ & 5.018 & 0.412 \\
& $2.5-7.5$ & 3.783 & 0.286 \\
& $7.5-12.5$ & 2.200 & 0.519 \\
\hline BrC $^{\mathrm{b}}$ - Experiment 1 & $0-2.5$ & 10.618 & 0.188 \\
& $2.5-7.5$ & 8.024 & 0.051 \\
& $7.5-12.5$ & 2.582 & 0.482 \\
\hline BrC $^{\mathrm{b}}$ - Experiment 2 & $0-2.5$ & 4.425 & 0.441 \\
& $2.5-7.5$ & 3.395 & 0.304 \\
& $7.5-12.5$ & 1.767 & 0.599 \\
\hline
\end{tabular}

${ }^{\mathrm{a}}\left(\mathrm{ppb}=\mu \mathrm{g} \mathrm{L} \mathrm{L}^{-1}=\mathrm{mg} \mathrm{m}^{-3}\right){ }^{\mathrm{b}} \mathrm{BrC}$ TOC is the difference between TOC from the deposition and the natural snow.
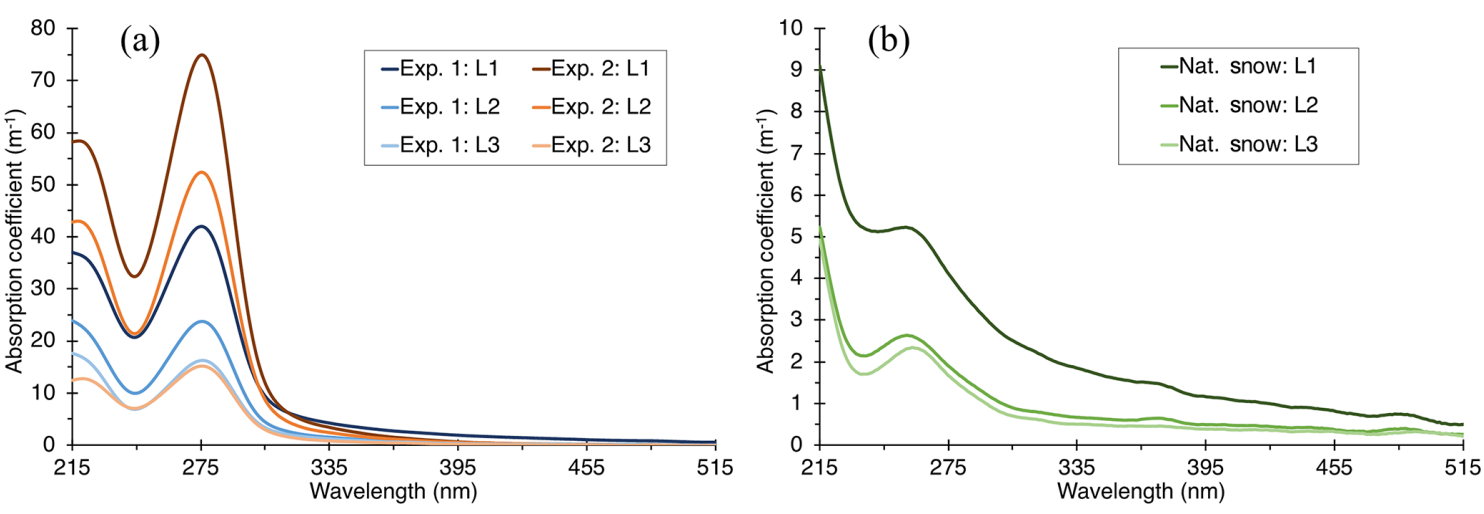

Figure 4. Absorption coefficient of snow meltwater for layers L1, L2, and L3 for deposited BrC (a) and for background impurities occurring in the natural snowpack (b). "Exp. 1" and "Exp. 2" refer to the first and second BrC deposition experiments, respectively. The spectra of the natural snow (b) have been averaged for two locations at the experiment site.

After determining $\kappa_{\text {bulk }}$, we calculated the absorption co-

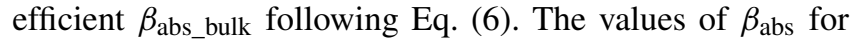
deposited $\mathrm{BrC}, \beta_{\mathrm{abs} \_\mathrm{BrC}}$, are found by subtracting the natural snowpack meltwater absorption coefficient averaged over the two natural snowpack sampling sites, denoted as $\beta_{\text {abs_snow, }}$, from that of the deposited $\mathrm{BrC}$-snow meltwater, denoted as $\beta_{\text {abs_bulk }}$; spectra calculated for $\beta_{\text {abs_BrC }}$ and $\beta_{\text {abs_snow }}$ can be found in Fig. 4. Indicative of $\mathrm{BrC}$ in water and aerosol, absorption spectra of meltwater from all samples exhibited a general increase in absorption with decreasing wavelength through the visible wavelength range, as well as peaks in the UV. $\beta_{\text {abs_snow }}$ spectra had a local absorption peak near $\sim 258 \mathrm{~nm}$. The UV absorption band in the presence of an aromatic nuclei (no other functional group specified) can be around $255 \mathrm{~nm}$ (Pretsch et al., 2000; Samburova et al., 2016), which is very close to our observed $\beta_{\text {abs_snow values. The }}$ presence of aromatic nuclei in the absorption spectra may be attributed to the traffic emissions near the field site or to decomposition of indigenous biogenic compounds in the atmosphere and snow surface. With the deposition of $\mathrm{BrC}$ aerosol to the snowpack, the absorption increased significantly in the short-visible and UV wavelength ranges and created a more prominent local absorption maximum at $275 \mathrm{~nm}$, with $\beta_{\text {abs_BrC }}$ spectra demonstrating a very similar pattern to phe- 
nolic compounds, ubiquitous in biomass combustion (Yee et al., 2013), with two peaks around 210 and $275 \mathrm{~nm}$ and a shoulder around $240 \mathrm{~nm}$ (Linstrom and Mallard, 2018). The preponderance of phenolic compounds in absorption spectra over other chemical classes makes them potential markers for $\mathrm{BrC}$ deposition on snow. However, the fate of such phenolic compounds on snow surface, through photochemical processing, for example, is still unknown and should be further investigated.

The calculated absorption coefficients correlate positively with measured TOC mass concentration of these samples. The slope of the linear regression between absorption coefficient $\left(\mathrm{m}^{-1}\right)$ at wavelength $\lambda$ and TOC concentrations gives the (mass) specific absorbance, $B_{\lambda}\left(\mathrm{m}^{2} \mathrm{~g}^{-1}\right)$, which is an indicator of the contribution by OC to the absorption coefficient in snow and ice (Warren et al., 2019; Zhang et al., 2019). $B_{\lambda}$ - sometimes referred to as specific absorbance - at various wavelengths is used to describe other properties, such as aromaticity of the OC (Hansen et al., 2016) and drinking water quality (Potter and Wimsatt, 2012), or is used to help describe different processes in rivers, lakes, and oceans (Fichot and Benner, 2011; Twardowski et al., 2004; Yacobi et al., 2003). The $B_{\lambda}$ spectrum over the wavelength range of $215-815 \mathrm{~nm}$ is presented in Fig. 5 along with the calculated correlation coefficient $R^{2}$ for each regression using $\mathrm{TOC}_{\mathrm{BrC}}$ concentrations together with those of the natural snowpack, $\mathrm{TOC}_{\text {snow }}$, as one dataset. The absorption is well explained $\left(R^{2}>0.9\right)$ by TOC in the meltwater throughout the UV, but above $353 \mathrm{~nm}$, the confidence in that relationship drops quickly $\left(R^{2}<0.5\right)$. If we consider just the natural snow samples, the calculated $R^{2}$ does not suggest high confidence $\left(R^{2}<0.7\right.$ across all wavelengths), likely due the low sample size $(n=6)$. For the natural snow samples, $B_{\lambda}$ is nearly equivalent to that of $\mathrm{BrC}$ at a wavelength of $258 \mathrm{~nm}$ $\left(B_{\lambda} \approx 7.3\right) . B_{\lambda}$ for the natural snowpack is 2 orders of magnitude greater than values inferred by Warren et al. (2019) for Alaskan sea ice at $400 \mathrm{~nm}$ but closer to that of snow and ice in the northern Tibetan Plateau (Yan et al., 2016).

The absorbance of $\mathrm{BrC}$ generally decreases with increasing wavelength, and a power-law relationship is often used to describe this wavelength dependence as

$p(\lambda)=c \lambda^{-\mathrm{AE}}$,

where $p$ is the parameter exhibiting the wavelength dependence, $c$ is a constant, and $\mathrm{AE}$ is the Ångström exponent (Ångström, 1929). For absorption, $p$ becomes the absorption coefficient $\beta_{\text {abs }}$, yielding the absorption Ångström exponent (AAE). The AAE can be written for two wavelengths as (Moosmüller et al., 2011)

$$
\begin{aligned}
& \frac{\beta_{\mathrm{abs}}\left(\lambda_{1}\right)}{\beta_{\mathrm{abs}}\left(\lambda_{2}\right)}=\left(\frac{\lambda_{1}}{\lambda_{2}}\right)^{-\mathrm{AAE}}, \\
& \operatorname{AAE}_{\lambda_{2}}^{\lambda_{1}}=-\frac{\ln \left(\beta_{\mathrm{abs}}\left(\lambda_{2}\right)\right)-\ln \left(\beta_{\mathrm{abs}}\left(\lambda_{1}\right)\right)}{\ln \left(\lambda_{2}\right)-\ln \left(\lambda_{1}\right)} .
\end{aligned}
$$

Zhang et al. (2019) have compiled a graphic (their Fig. 6) showing $\mathrm{AAE}_{400}^{330}$ values for several studies of $\mathrm{OC}$ in snow and the atmosphere. Our values for $\operatorname{AAE}_{400}^{330}(2.68,1.84$, and 1.48 for L1, L2, and L3, respectively) derived from the average natural snowpack $\beta_{\text {abs_snow }}$ are on the lower-end of their spectrum for AAEs of snow, close to the Zhang et al. (2019) results of OC in snow from the Altai Mountains and to that of Arctic snow (Doherty et al., 2010). $\mathrm{AAE}_{400}^{330}$ derived from $\beta_{\text {abs bulk }}$ in our study has a range from 4.12 to 6.28 (mean $=5.32$ ) for all layers; and, when considering $\beta_{\text {abs_BrC }}$, the larger $\mathrm{AAE}_{400}^{330}$ values are in the range of 4.86 to 9.79 (mean $=7.76$ ). Our values for BrC-only AAE over this wavelength range agree well with those presented in Fig. 6 of Zhang et al. (2019) for $\mathrm{BrC}$ aerosol in different regions of the world.

\subsubsection{Estimation of the imaginary refractive index, $\kappa$}

Equation (7) was used to estimate the imaginary part of the refractive index, $\kappa$, from each absorbance spectra. The volume mixing rule described in Eqs. (8) and (9) was used to normalize the calculated $\kappa$ for each spectrum using the $\mathrm{BrC}$ volume fraction measured for each sample to obtain $\kappa_{\mathrm{BrC}}$, the imaginary part of the $\mathrm{BrC}$ refractive index. The value of $\kappa_{\mathrm{BrC}}$ displayed in Fig. 6 represents that for all samples containing deposited $\mathrm{BrC}$ from $\mathrm{AK}$ peat combustion. The thin, dotted black lines represent the range of retrievals for $\kappa_{\mathrm{BrC}}$ for each snow sample from the deposition experiments, which incorporate the uncertainty of TOC concentrations assigned to each absorption spectrum of $\mathrm{BrC}$.

Comparing the values of $\kappa_{\mathrm{BrC}}$ obtained with this method to those of other selected studies for peat biomass combustion shows general agreement, with differences being greatest at different wavelength regions for different studies. Sumlin et al. (2018b) identified values of $\kappa_{\mathrm{BrC}}$ at four wavelengths $(375,405,532$, and $1047 \mathrm{~nm})$ under varying conditions of combustion for different peat fuels, including Alaskan peat; they identified the fuel packing density as the parameter dominating $\kappa_{\mathrm{BrC}}$ but found little dependence on the type of peat. Sengupta et al. (2018) estimated the refractive index of $\mathrm{BrC}$ from smoldering combustion of peat from Siberia (SBP, unpublished results) and Florida (FP), extracted in water. $\kappa_{\mathrm{BrC}}$ for SBP decreased with increasing wavelength faster than that from other peat samples in Fig. 6. In the visible part of the spectrum, the values of $\kappa_{\mathrm{BrC}}$ for FP smoke are in agreement with our results for AK peat smoke, while in the UV the largest qualitative difference is the presence of a peak at $275 \mathrm{~nm}$ in our spectrum; this peak is not discernible in the other spectra.

\subsubsection{Utilizing models for comparison with observations}

Using a complex index of refraction and particle size distribution as inputs to Mie theory, we estimate single-particle 

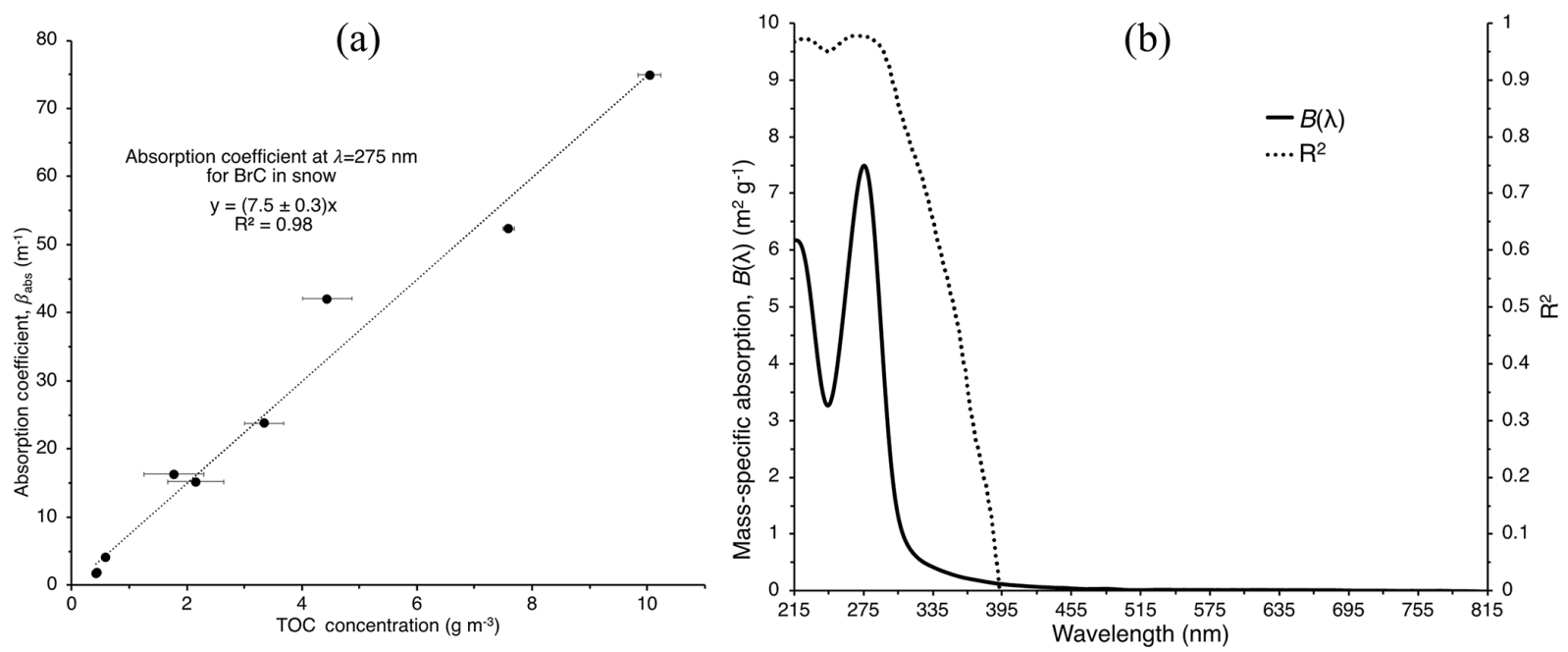

Figure 5. (a) Absorption coefficient at $275 \mathrm{~nm}$ as a function of total organic carbon (TOC) concentration. The fitted linear regression slope gives the mass-specific absorption $B_{\lambda}=7.5 \pm 0.3 \mathrm{~m}^{2} \mathrm{~g}^{-1}$ with a correlation coefficient of $R^{2}=0.98$. (b) Mass-specific absorption, $B(\lambda)$, and $R^{2}$ for each value of $B(\lambda)$ across the wavelength range $215-815 \mathrm{~nm}$ for $\mathrm{BrC}$ deposited experimentally and found in natural snow at Tamarack Lake together at a $1 \mathrm{~nm}$ resolution. These panels include absorption coefficients of all meltwater samples characterized in Fig. 2.

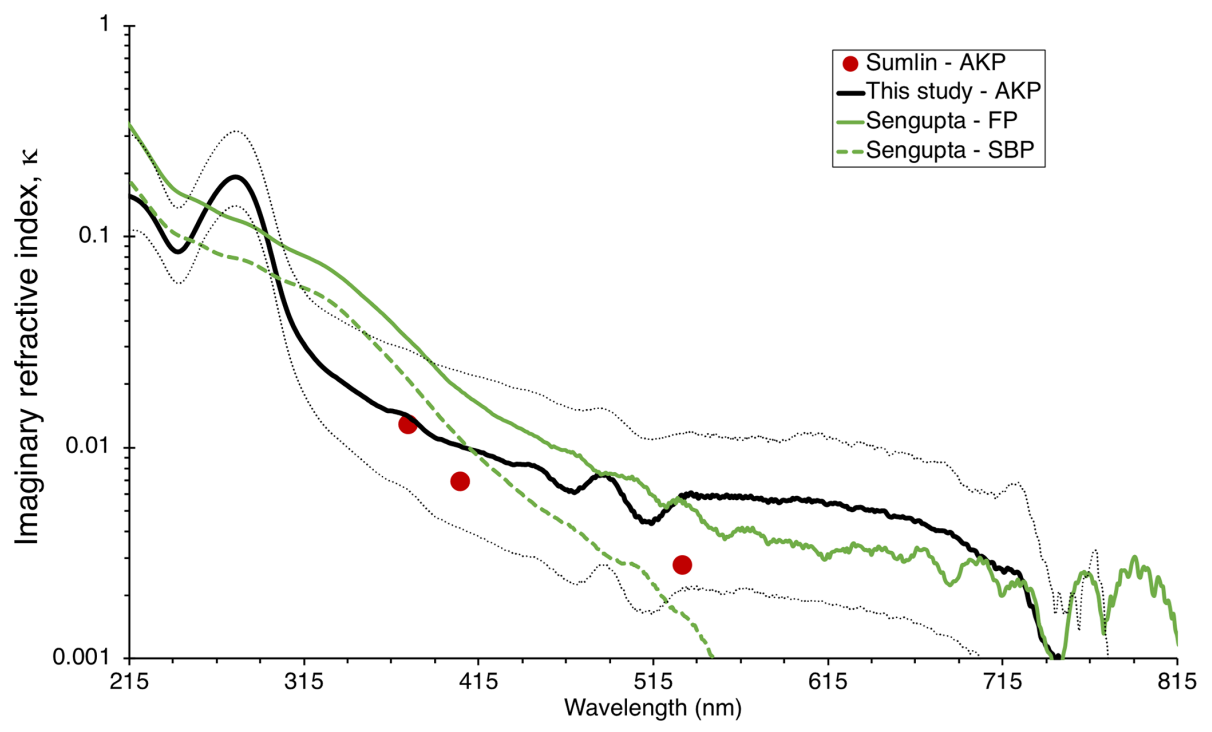

Figure 6. BrC imaginary refractive index, $\kappa_{\mathrm{BrC}}$, as estimated in this study and compared to values from other selected studies: Siberian peat (unpublished data) and Florida peat - SBP and FP, respectively - from Sengupta et al. (2018), and Alaskan peat (AKP) from this study and Sumlin et al. (2018b). The thin, dotted black lines indicate the upper and lower bounds of $\kappa_{\mathrm{BrC}}$ retrievals for this study.

optical properties of $\mathrm{BrC}$ under the assumption of homogeneous, spherical particles. These properties are inputs characterizing impurities for the SNICAR model (Flanner et al., 2007) to estimate spectral snow albedos over the wavelength range of 0.3 to $5.0 \mu \mathrm{m}$, enabling us to compare them to measured snow albedos that include the artificially deposited $\mathrm{BrC}$ as discussed in Sect. 3.1. We limit the reported albedo comparison to the wavelength range of $350-845 \mathrm{~nm}$ to match measured spectral albedo using $\mathrm{BrC}$ optical properties derived through UV-Vis spectroscopy.
Sumlin et al. (2018b) show that for BrC from combustion of AK peat, the real part of the refractive index, $n$, is insensitive to changes in fuel moisture content, source depth, and geographic origin and is constrained between 1.5 and 1.7. Because of this and the fact that no information exists regarding $n$ below $375 \mathrm{~nm}$ or above $1047 \mathrm{~nm}$ for AK peat, we use $n=1.6$ across the wavelength range of interest and, along with the range of values retrieved for $\kappa_{\mathrm{BrC}}$ in Sect. 2.2, as input for Mie theory calculations. We also utilize the Sumlin et al. (2018b) particle size distribution that was measured 

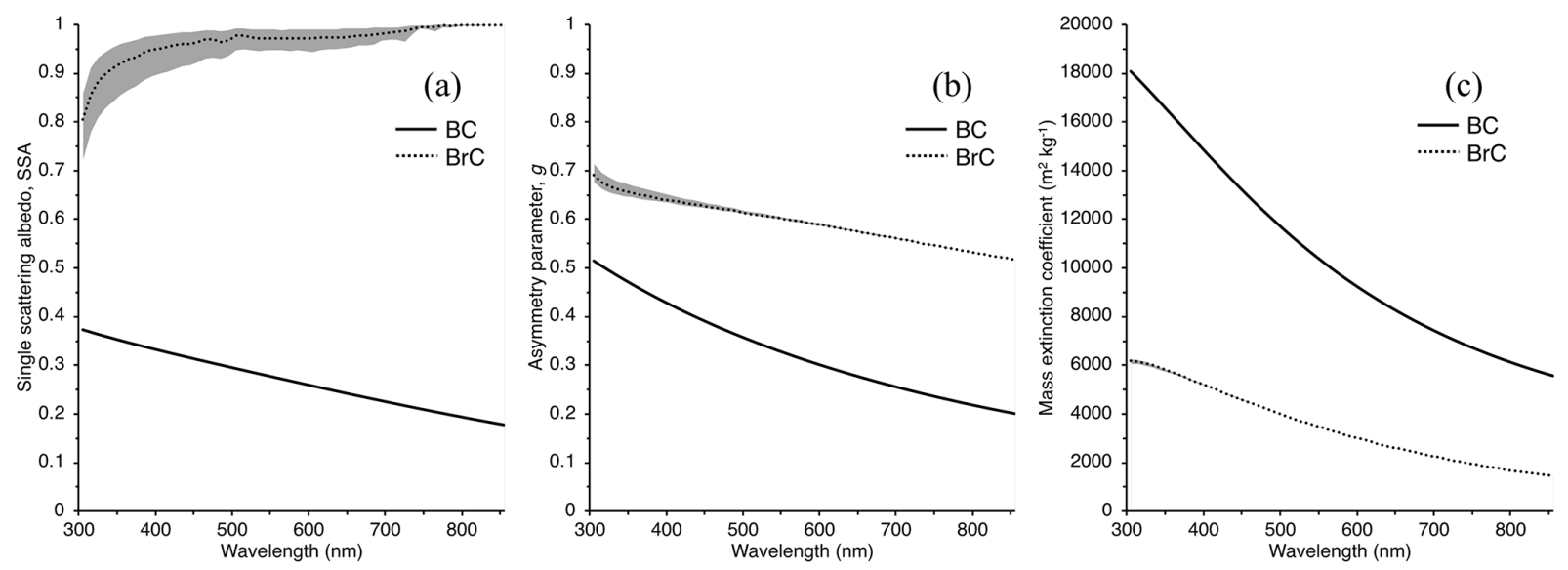

Figure 7. Single scattering albedo (SSA, a), asymmetry parameter $(g, \mathbf{b})$, and mass extinction coefficient $\left(\mathrm{MEC}, \mathrm{m}^{2} \mathrm{~kg}^{-1}, \mathbf{c}\right)$ of BrC derived using Mie theory. BC optical properties used in the SNICAR model are provided for reference. The grey area represents the outputs of each parameter for the range of $\kappa_{\mathrm{BrC}}$ retrievals used in the Mie code, where the largest relative discrepancy lies in the SSA. Note that the real refractive index for the calculations presented in this figure is assumed to be $n_{\lambda}=1.6$ across all wavelengths.

under similar combustion conditions as encountered in our study for AK peat with low fuel packing density and smoldering combustion for $35-40 \mathrm{~min}$. This lognormal distribution is described by a geometric mean diameter and standard deviation of $157 \mathrm{~nm}$ and 1.7, respectively. Mie theory calculations with our range of $\kappa_{\mathrm{BrC}}$ used as input into the Mie code return a range of single-particle properties for the single scattering albedo (SSA), asymmetry parameter $(g)$, and mass extinction coefficient (MEC, $\mathrm{m}^{2} \mathrm{~kg}^{-1}$ ) (Fig. 7). The average BrC SSA returned increases with increasing $\lambda$ close to a value of 1.0 near $\lambda=800 \mathrm{~nm}$. The SSA values in the UV and short visible wavelengths agree with those given by Sumlin et al. (2018b) in the UV and visible wavelength ranges, although they display the largest relative range of returned values from the Mie calculations, spanning $0.72-0.86$ at $305 \mathrm{~nm}$.

The widely used SNICAR model (Flanner et al., 2007) uses a two-stream radiative transfer scheme to simulate the optical properties of snow and ice in the presence of different types of impurities under different solar and snowpack conditions. The model user can specify multilayer snowpack properties, including individual layers, their snow densities and effective grain radii, and the concentrations of impurities, such as BC, an absorbing mineral dust in four size ranges, and/or volcanic ash. Impurity concentrations are specified for each individual layer, and impurities are treated as externally mixed with the ice grains. Optical properties (SSA, $g$, and MEC) for all impurities are described in lookup tables. Here, we incorporate our calculated SSA, $g$, and MEC for $\mathrm{AK}$ peat $\mathrm{BrC}$ into SNICAR and assign a $\mathrm{BrC}$ concentration in the modeled multilayer snowpack equal to that measured by TOC analysis.

For this study, the modeled albedo was first matched to measured spectral albedo of the natural snowpack along the UV-visible wavelength range, considering both the observed snowpack properties and solar geometry for the measurement day and time. The average TOC concentration for the natural snow layers (L1, L2, and L3) is input as $\mathrm{BrC}$ concentration, and values for $\mathrm{BC}$ and mineral dust are added to match the modeled albedo to the measured albedo. Once reasonable agreement $(\Delta$ albedo $\leq 0.025)$ is achieved for the natural snowpack measured and average modeled albedos across the wavelength range, the solar geometry, snowpack properties, and $\mathrm{BrC}$ concentration are updated to reflect that of the $\mathrm{BrC}$ deposition; results are presented in Fig. 8. Using this method, the difference in spectral albedo along the wavelength range in question was less than 0.15 for the deposited $\mathrm{BrC}$ for both deposition experiments. The modeled albedo for Experiment 1 generally matched the measured albedo better than Experiment 2, especially when considering the upper and lower bounds of $\mathrm{BrC}$ optical properties (shaded regions in figures). However, for Experiment 2, the additional deposited $\mathrm{BrC}$ resulted in an averaged modeled spectral albedo significantly lower (up to $\Delta$ albedo $=0.063$ ) than the measured albedo throughout most of the visible and short-visible wavelength ranges. For Experiment 1, the modeled albedo in the NIR for the natural snowpack did not match that of the measured albedo $(\Delta$ albedo $<0.025)$ without adding more $\mathrm{BC}$ and removing the mineral dust concentration nearly completely, which is unrealistic for the Sierra Nevada snow during the winter-spring transition. Additionally, adding more $\mathrm{BC}$ would have lowered the albedo across the entire wavelength range of interest and not just in the NIR.

\subsubsection{Estimating the radiative forcing by $\mathrm{BrC}$ deposition}

Because spectral albedo was measured before and after $\mathrm{BrC}$ aerosol deposition, we can directly assess the enhanced ab- 

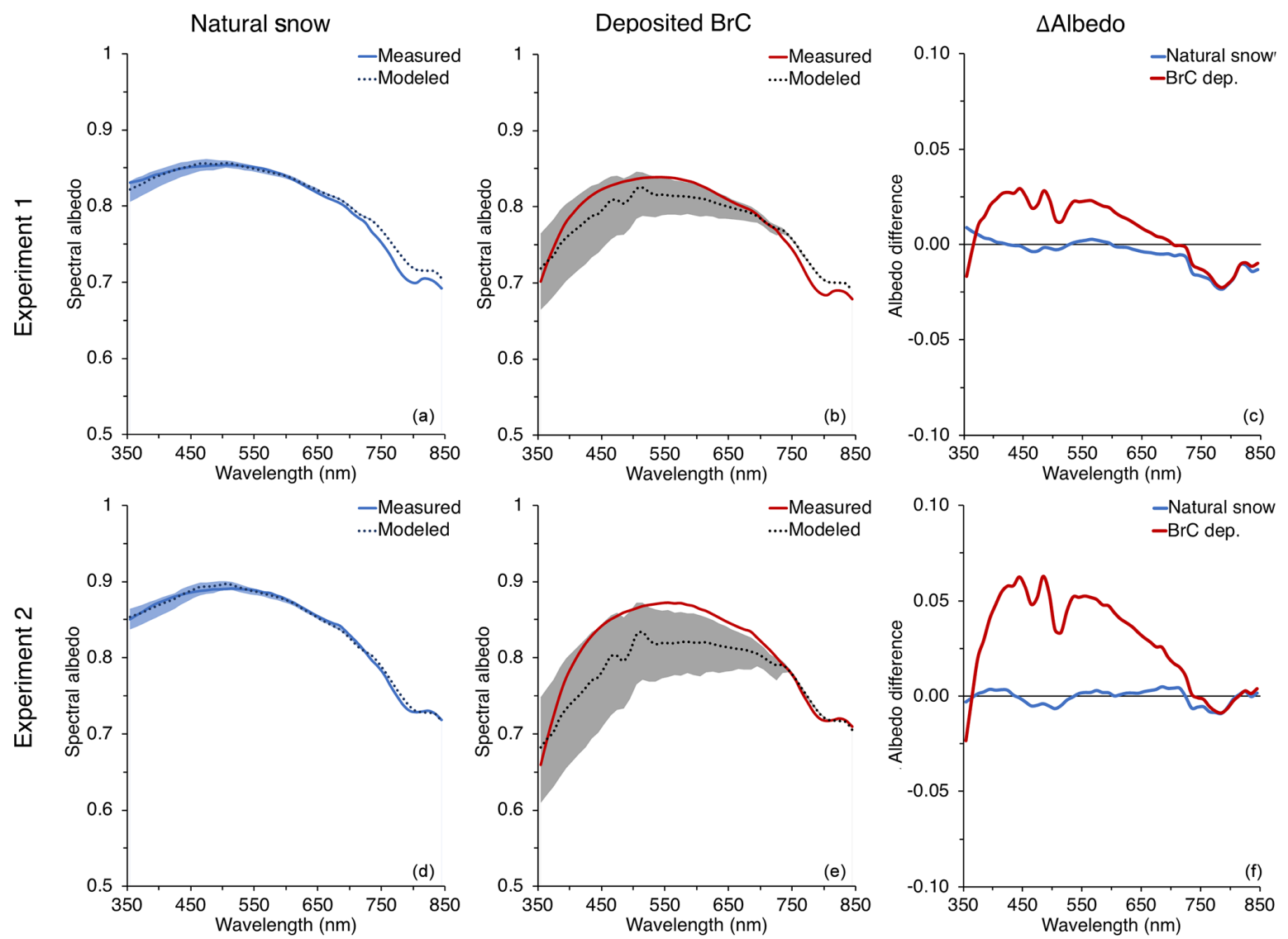

Figure 8. Comparisons of measured and modeled spectral albedos and their differences for Experiment 1 (a, b, c) and Experiment 2 (d, e, f). The left column shows modeled and measured albedo of the natural snowpack at Tamarack Lake, NV. The middle column shows the measured albedo compared to SNICAR-calculated albedo by adding concentrations of deposited BrC into the model. The right column represents the difference between the measured albedo and the mean modeled albedo for the natural snow and deposited $\mathrm{BrC}$. The range of modeled albedos from the range of $\kappa_{\mathrm{BrC}}$ retrievals for $\mathrm{BrC}$ deposited is represented by shaded regions in the left and middle columns.

sorption of solar radiation from the deposited $\mathrm{BrC}$ by estimating the increase in instantaneous radiative forcing (RF) and due to the presence of light-absorbing impurities as

$\mathrm{RF}=\sum_{\lambda_{1}}^{\lambda_{2}} I \Delta a \Delta \lambda$

where $I$ is the measured surface spectral irradiance, and $\Delta a$ is the difference between the spectral albedo of snow in the presence and absence of impurities between the wavelengths $\lambda_{1}$ and $\lambda_{2}$. For this study, $\lambda_{1}=350 \mathrm{~nm}$ (the shortest wavelength used) and $\lambda_{2}=1000 \mathrm{~nm}$, where we expect very little change due to the presence of impurities (Painter et al., 2013). Pure snow albedo is estimated through SNICAR and incorporating snowpack and sky conditions. Before $\mathrm{BrC}$ deposition, the natural snowpack had an instantaneous radiative forcing of 51.7 and $35.2 \mathrm{~W} \mathrm{~m}^{-2}$ for the two natural snow sites at Tamarack Lake, where the spectral albedo measured included all light-absorbing impurities inherently present. Considering the difference in measured spectral albedo of the natural snowpack and after depositing $\mathrm{BrC}$ aerosol from the combustion of AK peat (Fig. 3), the deposition experiment added an additional 14.0 and $19.8 \mathrm{~W} \mathrm{~m}^{-2}$, for a total instantaneous RF of 65.7 and $55.0 \mathrm{~W} \mathrm{~m}^{-2}$ for Experiment 1 and 2 , respectively. If we integrate the deposited $\mathrm{BrC}$ concentrations for L1, L2, and L3 for each deposition, the result is an average mass-weighted instantaneous RF efficiency of 1.23 $(+0.14 /-0.11) \mathrm{W} \mathrm{m}^{-2}$ per part per million $(\mathrm{ppm})$ of $\mathrm{BrC}$ (or OC) aerosol deposited from the combustion of AK peat.

The radiative impact of the deposition of light-absorbing impurities in snow is dependent on multiple variables including snow age (i.e., grain size), existing impurity content prior to deposition, and solar/sky conditions (Skiles et al., 2018). The rate at which the albedo is lowered, and thus the RF increases, by increasing total impurity loading decreases as the impurity concentration increases, a direct result of the great differences between the absorption properties of the impurities and that of ice itself in the UV-visible wavelength ranges (Warren and Wiscombe, 1980). We have calculated the RF efficiency increases from $1.23(+0.14 /-0.11) \mathrm{W} \mathrm{m}^{-2}$ per ppm of $\mathrm{BrC}$ deposited to $2.68(+0.27 /-0.22) \mathrm{W} \mathrm{m}^{-2}$ per $\mathrm{ppm}$ of $\mathrm{BrC}$ deposited onto a pristine snowpack. 


\section{Addressing uncertainty and sources of error}

This study provided an estimation of the imaginary refractive index $\kappa$ of $\mathrm{BrC}$ artificially deposited on a snowpack. While the authors have taken care to limit the amount of uncertainty throughout the study, the analyses and calculations used in this study are not without assumptions and sources of error. These are addressed below.

\subsection{Deposition experiment, spectral albedo measurement, and snow sample collection}

Artificially depositing aerosols onto the snow surface is a proven method to study aerosol-cryosphere interactions (Beres and Moosmüller, 2018; Brandt et al., 2011; Conway et al., 1996; Peltoniemi et al., 2015). For this study, aerosol deposition, spectral albedo measurement, and the collection of snow samples were conducted as quickly as possible while minimizing contamination in an effort to reduce uncertainties discussed below.

One limitation of the deposition apparatus and measuring the hemispherical spectral albedo of the subsequent deposited aerosols is the limited areal extent of deposited material when compared to the viewing angle of the cosinecorrected receptor. Because the deposition area is not infinite, there will be a fraction of reflected light from the surrounding ambient snowpack that will influence the measured spectral albedo; however, this fraction of information is reduced for greater angles. Great care was taken during the experiment to minimize the effect from instrument shadowing while decreasing the distance between the optical detector and the snow surface. As such, a majority of the reflected signal is from within the deposition area and some information is from the surrounding natural snowpack.

In this experiment, the deposition apparatus increased the snow effective grain radii at the snow surface through localized heating due to covering the snowpack with the deposition volume during ambient conditions of warm temperatures and high solar insolation. While temperature inside the deposition volume was not monitored, this effect was observed by examining the difference in measured NIR $(700-1300 \mathrm{~nm})$ albedo, where snow reflectance is most sensitive to changes in grain size. Additionally, the presence of liquid water may also have been enhanced due to this local heating of the snow surface, and the induced melt may have contributed to impurities percolating lower into the snowpack.

Another important observation made over several $\mathrm{BrC}$ deposition experiments is the loss of $\mathrm{BrC}$ absorption over time. While the spectral albedo measurements in our study were made within $5 \mathrm{~min}$ of aerosol deposition, and likely were not affected significantly by this phenomenon, unpublished data of the hemispherical-conical reflectance factor (HCRF, Schaepman-Strub et al., 2006) of the snow surface after the deposition of $\mathrm{BrC}$ aerosols from $\mathrm{AK}$ peat and another $\mathrm{BrC}$ aerosol-producing surrogate fuel (i.e., incense, Chakrabarty et al., 2013 and Gyawali et al., 2012) showed that the UV reflectance increased over some time after deposition. In one instance, the HCRF at $350 \mathrm{~nm}$ increased from 0.69 to 0.83 in 207 min, whereas the HCRF of the natural snow nearby did not exhibit any discernible change over the same time period. We hypothesize that there are a couple factors that may have contributed to this increase. First, experiments were conducted during the winter-spring seasonal transition, where warm air temperatures induced melt in the surface layer(s) of the snow (the snowpack was not isothermal). Liquid water present in the snowpack flushes water-soluble OC compounds through the snowpack, which may have occurred in the top layers of the snow. Secondly, high UV solar irradiance may photobleach, and heat from absorbed radiation may volatilize chromophoric organic compounds (Bertilsson and Tranvik, 2000; Grannas et al., 2007; Laskin et al., 2015; Sumlin et al., 2017). These absorption-reducing photochemical processes may also apply to $\mathrm{BrC}$ aerosol deposited on snow, and the resulting change in snowpack chemistry and optics are not fully understood. Likely, the reason for the reduction in absorption is a combination of above scenarios, and further work is needed to quantify these effects.

\subsection{TOC concentration measurements}

The concentrations of TOC presented in this paper represent those of melted snow and its impurities. However, while care was taken to minimize the contamination of snow samples collected, a small amount of TOC was likely scavenged from the Whirl-Pak plastic bags used to store and transport snow samples. We have derived an upper limit of this effect by measuring the TOC concentration of UPW shaken in new Whirl-Pak bags to be $0.493 \pm 0.025 \mathrm{~g} \mathrm{~m}^{-3}$; we consider this to be the upper limit of contamination from liquid water interacting with the Whirl-Pak bags, and we would expect this value to be much smaller as our samples remained frozen until TOC determination. Additionally for this study, we did not filter the samples prior to TOC determination, as many studies have done using 0.45 or $0.22 \mu \mathrm{m}$ pore size filters, to determine dissolved organic carbon (DOC). Instead, we assume that the total OC measured represents water-soluble and insoluble OC as well as particulate and nonparticulate OC. With regard to soluble versus insoluble $\mathrm{OC}$, the manufacturer of the instrument used for this study states that the recovery of insoluble OC in the instrument is greater than $90 \%$. There are no data from the manufacturer regarding particulate $\mathrm{OC}$ (POC) versus nonparticulate $\mathrm{OC}$ measured using a TOC analyzer; however, Potter and Wimsatt (2012) indirectly indicate that the mean DOC and TOC concentrations measured for seven unfortified source waters showed a nearly one-to-one relationship (TOC $=1.09$. DOC; $R^{2}=0.997$ ) using a similar instrument to the one used in this study. Additionally, the fraction of light-absorbing organic carbon versus non-lightabsorbing organic carbon is not known to us for this particular fuel and combustion scenario, and, for this study, we 
do not attempt to resolve it. However, throughout the optical measurements (snow surface albedo and spectrophotometric absorbance of melted snow samples), we consistently measure the same organic material without filtering. This way, we consistently use an average absorption of all organic compounds present and isolate those from the deposition experiment to those in the natural snow by using background subtraction.

\subsection{Absorbance and determination of $\kappa_{\mathrm{BrC}}$}

Measurement of the UV-Vis absorbance is a common practice to determine the optical properties of atmospheric aerosols and impurities in rivers, lakes, oceans, and snow and ice. However, there are some uncertainties with regard to these methods.

While the authors assume that all of the measured absorption from impurities in the melted snow samples is solely due to $\mathrm{BrC}$, it is likely that small fractions of $\mathrm{BC}$ (both from the deposition experiment as well as naturally occurring) and light-absorbing mineral dusts are present as well, and mineral dust poses a particular risk in assessing $\kappa_{\mathrm{BrC}}$. The absorption of atmosphere mineral dusts is typically dominated by iron components (e.g., hematite, goethite), particularly in the UV and at short visible wavelengths (Engelbrecht et al., 2016; Moosmüller et al., 2009; Sokolik and Toon, 1999; Zhang et al., 2015). Skiles et al. (2017) developed a method to determine $\kappa$ for dusts found in the snow of Colorado mountains in high concentrations, but there has been no similar study performed for impurities in Sierra Nevada snow, where sources are much different. Sterle et al. (2013) found dust mass concentrations in the upper $30 \mathrm{~cm}$ of snow in the eastern Sierra Nevada to be between 1 and 44 ppm in the 2008-2009 winter season, which is not insignificant. Here, we made no attempt to measure the concentrations of mineral dust, BC, or other inorganic material in Sierra Nevada snow.

In addition, some of the raw, high-spectral-resolution absorbance data had a poor signal-to-noise ratio; we improved this by smoothing the raw absorbance spectra through a moving average smoothing algorithm of 15 data points (corresponding to $15 \mathrm{~nm}$ ) on either side of the data point in question.

\section{Summary}

Light-absorbing OC (or BrC) from smoldering biomass combustion present near snow and ice environments induces UV and short-visible light absorption that has previously been unaccounted for in snow albedo, energy balance, and radiative forcing modeling. Biomass combustion of peat at high latitudes of the Northern Hemisphere has particular potential for reducing snow and ice albedo due to the close proximity of snow and ice to BrC-rich emissions from peatland wildfires at high latitudes.
This study provides a first estimation of the spectral signatures of $\mathrm{BrC}$ particulate matter, from peat biomass combustion, present in the snowpack. Previously, Beres and Moosmüller (2018) have artificially deposited combustion aerosols directly onto and into the snowpack. They have shown that the deposition of emissions from small-scale smoldering combustion of Alaskan peat is effective in altering the snow surface reflectivity, especially in the UV and short-visible wavelength region. Here, we utilized this same method, together with UV-Vis spectroscopy of melted snow samples, TOC concentrations in the snow before and after deposition, and Mie-theory-calculated optical properties, to estimate the imaginary refractive index of deposited $\mathrm{BrC}$. This method has been shown to generally agree with other studies investigating these optical properties, and, by incorporating a range of derived values into SNICAR, modeled spectral albedos are shown to agree with measured albedos as well, within $5 \%$ across the UV-visible wavelength region. The instantaneous radiative forcing of $\mathrm{BrC}$ deposited onto the natural snowpack was shown to have a mass-weighted value of $1.23(+0.14 /-0.11) \mathrm{W} \mathrm{m}^{-2}$ per ppm of BrC (or combustion OC) deposited, while deposition onto a clean (without other light-absorbing impurities) snowpack would have resulted in a more than twice as large instantaneous radiative forcing of $2.68(+0.27 /-0.22) \mathrm{W} \mathrm{m}^{-2}$ per ppm of $\mathrm{BrC}$ deposited. These results can further inform the impact of deposited combustion aerosol on snow albedo and radiative forcing. In addition to the $\mathrm{RF}, \mathrm{BrC}$ deposition can greatly reduce $U V$ actinic flux, thereby reducing photochemistry in the snowpack. Further investigations are necessary to refine this method, as well as to address some uncertainty in the behavior of $\mathrm{BrC}$ in snow.

Data availability. Data presented and used throughout this study can be accessed through the following data repository: https://doi.org/10.5281/zenodo.3736325 (Beres et al., 2020).

Author contributions. NDB and HM designed the experiments and NDB, HM, and DS carried them out. NDB performed measurements and analysis of data. NDB and HM prepared the manuscript with contributions from DS, VS, and AYK.

Competing interests. The authors declare that they have no conflict of interest.

Acknowledgements. The authors acknowledge the support of Adam Watts for supplying the Alaskan peat samples, Michelle Matus for assisting with fieldwork during $\mathrm{BrC}$ depositions, and Nathan Chellman and the Ice Core Laboratory at the Desert Research Institute for help with TOC determination. The authors thank Jeff Dozier and three anonymous referees for their comments and suggestions to improve this paper. 
Financial support. This research has been supported by NASA (grant nos. NNX14AN24A and NNX15AI48G) and by NSF (grant no. AGS1544425).

Review statement. This paper was edited by Timothy Garrett and reviewed by three anonymous referees.

\section{References}

Andreae, M. O. and Gelencsér, A.: Black carbon or brown carbon? The nature of light-absorbing carbonaceous aerosols, Atmos. Chem. Phys., 6, 3131-3148, https://doi.org/10.5194/acp-63131-2006, 2006.

Ångström, A.: On the Atmospheric Transmission of Sun Radiation and on Dust in the Air, Geogr. Ann., 11, 156-166, https://doi.org/10.2307/519399, 1929.

Bahadur, R., Praveen, P. S., Xu, Y., and Ramanathan, V.: Solar absorption by elemental and brown carbon determined from spectral observations, P. Natl. Acad. Sci. USA, 109, 17366-17371, https://doi.org/10.1073/pnas.1205910109, 2012.

Beres, N. D. and Moosmüller, H.: Apparatus for dry deposition of aerosols on snow, Atmos. Meas. Tech., 11, 6803-6813, https://doi.org/10.5194/amt-11-6803-2018, 2018.

Beres, N. D., Sengupta, D., Samburova, V., Khlystov, A., and Moosmüller, H.: Dataset to accompany "Deposition of brown carbon onto snow: changes in snow optical and radiative properties" by Beres et al. (2020), Dataset, Zenodo, https://doi.org/10.5281/zenodo.3736326, 2020.

Bergstrom, R. W., Pilewskie, P., Russell, P. B., Redemann, J., Bond, T. C., Quinn, P. K., and Sierau, B.: Spectral absorption properties of atmospheric aerosols, Atmos. Chem. Phys., 7, 5937-5943, https://doi.org/10.5194/acp-7-5937-2007, 2007.

Bertilsson, S. and Tranvik, L. J.: Photochemical transformation of dissolved organic matter in lakes, Limnol. Oceanogr., 45, 753762, https://doi.org/10.4319/lo.2000.45.4.0753, 2000.

Bhattarai, C., Samburova, V., Sengupta, D., Iaukea-Lum, M., Watts, A. C., Moosmüller, H., and Khlystov, A. Y.: Physical and chemical characterization of aerosol in fresh and aged emissions from open combustion of biomass fuels, Aerosol Sci. Tech., 52, 12661282, https://doi.org/10.1080/02786826.2018.1498585, 2018.

Bond, T. C. and Bergstrom, R. W.: Light absorption by carbonaceous particles: An investigative review, Aerosol Sci. Tech., 40, 27-67, https://doi.org/10.1080/02786820500421521, 2006.

Bond, T. C., Streets, D. G., Yarber, K. F., Nelson, S. M., Woo, J. H., and Klimont, Z.: A technology-based global inventory of black and organic carbon emissions from combustion, J. Geophys. Res.-Atmos., 109, 1-43, https://doi.org/10.1029/2003JD003697, 2004.

Bond, T. C., Doherty, S. J., Fahey, D. W., Forster, P. M., Berntsen, T., DeAngelo, B. J., Flanner, M. G., Ghan, S., Kärcher, B., Koch, D., Kinne, S., Kondo, Y., Quinn, P. K., Sarofim, M. C., Schultz, M. G., Schulz, M., Venkataraman, C., Zhang, H., Zhang, S., Bellouin, N., Guttikunda, S. K., Hopke, P. K., Jacobson, M. Z., Kaiser, J. W., Klimont, Z., Lohmann, U., Schwarz, J. P., Shindell, D., Storelvmo, T., Warren, S. G., and Zender, C. S.: Bounding the role of black carbon in the climate system: A sci- entific assessment, J. Geophys. Res.-Atmos., 118, 5380-5552, https://doi.org/10.1002/jgrd.50171, 2013.

Bosch, C., Andersson, A., Kirillova, E. N., Budhavant, K., Tiwari, S., Praveen, P. S., Russell, L. M., Beres, N. D., Ramanathan, V., and Gustafsson, Ö.: Source-diagnostic dual-isotope composition and optical properties of water-soluble organic carbon and elemental carbon in the South Asian outflow intercepted over the Indian Ocean, J. Geophys. Res.-Atmos., 119, 11743-11759, https://doi.org/10.1002/2014JD022127, 2014.

Brandt, R. E., Warren, S. G., and Clarke, A. D.: A controlled snowmaking experiment testing the relation between black carbon content and reduction of snow albedo, J. Geophys. Res., 116, D08109, https://doi.org/10.1029/2010JD015330, 2011.

Brown, D. R. N., Jorgenson, M. T., Douglas, T. A., Romanovsky, V. E., Kielland, K., Hiemstra, C., Euskirchen, E. S., and Ruess, R. W.: Interactive effects of wildfire and climate on permafrost degradation in Alaskan lowland forests, J. Geophys. Res.-Biogeo., 120, 1619-1637, https://doi.org/10.1002/2015JG003033, 2015.

Carlton, A. G., Turpin, B. J., Altieri, K. E., Seitzinger, S., Reff, A., Lim, H. J., and Ervens, B.: Atmospheric oxalic acid and SOA production from glyoxal: Results of aqueous photooxidation experiments, Atmos. Environ., 41, 7588-7602, https://doi.org/10.1016/j.atmosenv.2007.05.035, 2007.

Cereceda-Balic, F., Gorena, T., Soto, C., Vidal, V., Lapuerta, M., and Moosmüller, H.: Optical determination of black carbon mass concentrations in snow samples: A new analytical method, Sci. Total Environ., 6987, 133934, https://doi.org/10.1016/j.scitotenv.2019.133934, 2019.

Chakrabarty, R. K., Moosmüller, H., Chen, L.-W. A., Lewis, K., Arnott, W. P., Mazzoleni, C., Dubey, M. K., Wold, C. E., Hao, W. M., and Kreidenweis, S. M.: Brown carbon in tar balls from smoldering biomass combustion, Atmos. Chem. Phys., 10, 6363 6370, https://doi.org/10.5194/acp-10-6363-2010, 2010.

Chakrabarty, R. K., Arnold, I. J., Francisco, D. M., Hatchett, B., Hosseinpour, F., Loria, M., Pokharel, A., and Woody, B. M.: Black and brown carbon fractal aggregates from combustion of two fuels widely used in Asian rituals, J. Quant. Spectrosc. Ra., 122, 25-30, https://doi.org/10.1016/j.jqsrt.2012.12.011, 2013.

Chakrabarty, R. K., Gyawali, M., Yatavelli, R. L. N., Pandey, A., Watts, A. C., Knue, J., Chen, L.-W. A., Pattison, R. R., Tsibart, A., Samburova, V., and Moosmüller, H.: Brown carbon aerosols from burning of boreal peatlands: microphysical properties, emission factors, and implications for direct radiative forcing, Atmos. Chem. Phys., 16, 3033-3040, https://doi.org/10.5194/acp-16-3033-2016, 2016.

Chen, L.-W. A., Moosmüller, H., Arnott, W. P., Chow, J. C., Watson, J. G., Susott, R. a., Babbitt, R. E., Wold, C. E., Lincoln, E. N., and Hao, W. M.: Particle emissions from laboratory combustion of wildland fuels: In situ optical and mass measurements, Geophys. Res. Lett., 33, L04803, https://doi.org/10.1029/2005GL024838, 2006.

Chýlek, P., Ramaswamy, V., and Srivastava, V.: Albedo of soot-contaminated snow, J. Geophys. Res., 88, 10837, https://doi.org/10.1029/JC088iC15p10837, 1983.

Chýlek, P., Srivastava, V., Pinnick, R. G., and Wang, R. T.: Scattering of electromagnetic waves by composite spherical particles: experiment and effective medium approximations, Appl. Optics, 27, 2396, https://doi.org/10.1364/AO.27.002396, 1988. 
Clifton, A., Manes, C., Rüedi, J.-D., Guala, M., and Lehning, M.: On Shear-Driven Ventilation of Snow, Bound.-Lay. Meteorol., 126, 249-261, https://doi.org/10.1007/s10546-007-9235-0, 2008.

Colbeck, S. C.: Model of wind pumping for layered snow, J. Glaciol., 43, 60-65, https://doi.org/10.1017/S002214300000280X, 1997.

Conway, H., Gades, A., and Raymond, C. F.: Albedo of dirty snow during conditions of melt, Water Resour. Res., 32, 1713-1718, https://doi.org/10.1029/96WR00712, 1996.

Corr, C. A., Hall, S. R., Ullmann, K., Anderson, B. E., Beyersdorf, A. J., Thornhill, K. L., Cubison, M. J., Jimenez, J. L., Wisthaler, A., and Dibb, J. E.: Spectral absorption of biomass burning aerosol determined from retrieved single scattering albedo during ARCTAS, Atmos. Chem. Phys., 12, 10505-10518, https://doi.org/10.5194/acp-12-10505-2012, 2012.

Dang, C. and Hegg, D. A.: Quantifying light absorption by organic carbon in Western North American snow by serial chemical extractions, J. Geophys. Res.-Atmos., 119, 10247-10261, https://doi.org/10.1002/2014JD022156, 2014.

Davis, R. E., Nolin, A. W., Jordan, R., and Dozier, J.: Towards predicting temporal changes of the spectral signature of snow in visible and near-infrared wavelengths, Ann. Glaciol., 17, 143-148, https://doi.org/10.3189/S026030550001274X, 1993.

Déry, S. J. and Brown, R. D.: Recent Northern Hemisphere snow cover extent trends and implications for the snow-albedo feedback, Geophys. Res. Lett., 34, 2-7, https://doi.org/10.1029/2007GL031474, 2007.

Doherty, S. J., Warren, S. G., Grenfell, T. C., Clarke, A. D., and Brandt, R. E.: Light-absorbing impurities in Arctic snow, Atmos. Chem. Phys., 10, 11647-11680, https://doi.org/10.5194/acp-1011647-2010, 2010.

Doherty, S. J., Grenfell, T. C., Forsström, S., Hegg, D. L., Brandt, R. E., and Warren, S. G.: Observed vertical redistribution of black carbon and other insoluble light-absorbing particles in melting snow, J. Geophys. Res.-Atmos., 118, 5553-5569, https://doi.org/10.1002/jgrd.50235, 2013.

Domine, F., Albert, M., Huthwelker, T., Jacobi, H.-W., Kokhanovsky, A. A., Lehning, M., Picard, G., and Simpson, W. R.: Snow physics as relevant to snow photochemistry, Atmos. Chem. Phys., 8, 171-208, https://doi.org/10.5194/acp-8171-2008, 2008.

Dozier, J. and Painter, T. H.: Multispectral and Hyperspectral Remote Sensing of Alpine Snow Properties, Annu. Rev. Earth Planet. Sc., 32, 465-494, https://doi.org/10.1146/annurev.earth.32.101802.120404, 2004.

Einfeld, W., Ward, D. E., and Hardy, C.: Effects of fire behavior on prescribed fire smoke characteristics: A case study, in Global Biomass Burning: Atmospheric, Climate, and Biospheric Implications, edited by: Levine, J. S., 209-224, Massachusetts Institute of Technology Press, 1991.

Engelbrecht, J. P., Moosmüller, H., Pincock, S., Jayanty, R. K. M., Lersch, T., and Casuccio, G.: Technical note: Mineralogical, chemical, morphological, and optical interrelationships of mineral dust re-suspensions, Atmos. Chem. Phys., 16, 10809-10830, https://doi.org/10.5194/acp-16-10809-2016, 2016.

Ervens, B., Feingold, G., Frost, G. J., and Kreidenweis, S. M.: A modeling of study of aqueous production of dicarboxylic acids: 1. Chemical pathways and speciated or- ganic mass production, J. Geophys. Res.-Atmos., 109, 1-20, https://doi.org/10.1029/2003JD004387, 2004.

Evangeliou, N., Kylling, A., Eckhardt, S., Myroniuk, V., Stebel, K., Paugam, R., Zibtsev, S., and Stohl, A.: Open fires in Greenland in summer 2017: transport, deposition and radiative effects of BC, OC and BrC emissions, Atmos. Chem. Phys., 19, 1393-1411, https://doi.org/10.5194/acp-19-1393-2019, 2019.

Fain, X., Ferrari, C. P., Gauchard, P.-A., Magand, O., and Boutron, C.: Fast depletion of gaseous elemental mercury in the Kongsvegen Glacier snowpack in Svalbard, Geophys. Res. Lett., 33, L06826, https://doi.org/10.1029/2005GL025223, 2006.

Fichot, C. G. and Benner, R.: A novel method to estimate DOC concentrations from CDOM absorption coefficients in coastal waters, Geophys. Res. Lett., 38, 1-5, https://doi.org/10.1029/2010GL046152, 2011.

Flanner, M. G., Zender, C. S., Randerson, J. T., and Rasch, P. J.: Present-day climate forcing and response from black carbon in snow, J. Geophys. Res., 112, D11202, https://doi.org/10.1029/2006JD008003, 2007.

Flannigan, M., Stocks, B., Turetsky, M., and Wotton, M.: Impacts of climate change on fire activity and fire management in the circumboreal forest, Glob. Change Biol., 15, 549-560, https://doi.org/10.1111/j.1365-2486.2008.01660.x, 2009.

Godec, R. D., Kosenka, P. P., and Hutte, R. S.: New Total Organic Carbon Analyzer, in SAE Technical Papers, Society of Automotive Engineers, Inc., Williamsburg, USA, 1990.

Graber, E. R. and Rudich, Y.: Atmospheric HULIS: How humiclike are they? A comprehensive and critical review, Atmos. Chem. Phys., 6, 729-753, https://doi.org/10.5194/acp-6-7292006, 2006.

Grannas, A. M., Jones, A. E., Dibb, J., Ammann, M., Anastasio, C., Beine, H. J., Bergin, M., Bottenheim, J., Boxe, C. S., Carver, G., Chen, G., Crawford, J. H., Dominé, F., Frey, M. M., Guzmán, M. I., Heard, D. E., Helmig, D., Hoffmann, M. R., Honrath, R. E., Huey, L. G., Hutterli, M., Jacobi, H. W., Klán, P., Lefer, B., McConnell, J., Plane, J., Sander, R., Savarino, J., Shepson, P. B., Simpson, W. R., Sodeau, J. R., von Glasow, R., Weller, R., Wolff, E. W., and Zhu, T.: An overview of snow photochemistry: evidence, mechanisms and impacts, Atmos. Chem. Phys., 7, 43294373, https://doi.org/10.5194/acp-7-4329-2007, 2007.

Green, M. C., Chen, L. W. A., DuBois, D. W and Molenar, J. V.: Fine particulate matter and visibility in the Lake Tahoe Basin: Chemical characterization, trends, and source apportionment, J. Air Waste Manage., 62, 953-965, https://doi.org/10.1080/10962247.2012.690362, 2012.

Grenfell, T. C., Doherty, S. J., Clarke, A. D., and Warren, S. G.: Light absorption from particulate impurities in snow and ice determined by spectrophotometric analysis of filters, Appl. Optics, 50, 2037, https://doi.org/10.1364/AO.50.002037, 2011.

Gyawali, M., Arnott, W. P., Zaveri, R. A., Song, C., Moosmüller, H., Liu, L., Mishchenko, M. I., Chen, L.-W. A., Green, M. C., Watson, J. G., and Chow, J. C.: Photoacoustic optical properties at UV, VIS, and near IR wavelengths for laboratory generated and winter time ambient urban aerosols, Atmos. Chem. Phys., 12, 2587-2601, https://doi.org/10.5194/acp-12-2587-2012, 2012.

Hadley, O. L., Corrigan, C. E., Kirchstetter, T. W., Cliff, S. S., and Ramanathan, V.: Measured black carbon deposition on the Sierra Nevada snow pack and implication for snow pack retreat, At- 
mos. Chem. Phys., 10, 7505-7513, https://doi.org/10.5194/acp10-7505-2010, 2010.

Hansen, A. M., Kraus, T. E. C., Pellerin, B. A., Fleck, J. A., Downing, B. D., and Bergamaschi, B. A.: Optical properties of dissolved organic matter (DOM): Effects of biological and photolytic degradation, Limnol. Oceanogr., 61, 1015-1032, https://doi.org/10.1002/lno.10270, 2016.

Hansen, J. and Nazarenko, L.: Soot climate forcing via snow and ice albedos, P. Natl. Acad. Sci. USA, 101, 423-428, https://doi.org/10.1073/pnas.2237157100, 2004.

Harder, S. L., Warren, S. G., Charlson, R. J., and Covert, D. S.: Filtering of air through snow as a mechanism for aerosol deposition to the Antarctic ice sheet, J. Geophys. Res.-Atmos., 101, 1872918743, https://doi.org/10.1029/96JD01174, 1996.

Honrath, R. E., Peterson, M. C., Guo, S., Dibb, J. E., Shepson, P. B., and Campbell, B.: Evidence of $\mathrm{NO}_{x}$ production within or upon ice particles in the Greenland snowpack, Geophys. Res. Lett., 26, 695-698, https://doi.org/10.1029/1999GL900077, 1999.

Honrath, R. E., Peterson, M. C., Dziobak, M. P., Dibb, J. E., Arsenault, M. A., and Green, S. A.: Release of $\mathrm{NO}(\mathrm{x})$ from sunlightirradiated midlatitude snow, Geophys. Res. Lett., 27, 2237-2240, https://doi.org/10.1029/1999GL011286, 2000.

Jacobson, M. Z.: Climate response of fossil fuel and biofuel soot, accounting for soot's feedback to snow and sea ice albedo and emissivity, J. Geophys. Res., 109, D21201, https://doi.org/10.1029/2004JD004945, 2004.

Jimenez, J. L., Canagaratna, M. R., Donahue, N. M., Prevot, A. S. H., Zhang, Q., Kroll, J. H., DeCarlo, P. F., Allan, J. D., Coe, H., Ng, N. L., Aiken, A. C., Docherty, K. S., Ulbrich, I. M., Grieshop, A. P., Robinson, A. L., Duplissy, J., Smith, J. D., Wilson, K. R., Lanz, V. A., Hueglin, C., Sun, Y. L., Tian, J., Laaksonen, A., Raatikainen, T., Rautiainen, J., Vaattovaara, P., Ehn, M., Kulmala, M., Tomlinson, J. M., Collins, D. R., Cubison, M. J., Dunlea, J., Huffman, J. A., Onasch, T. B., Alfarra, M. R., Williams, P. I., Bower, K., Kondo, Y., Schneider, J., Drewnick, F., Borrmann, S., Weimer, S., Demerjian, K., Salcedo, D., Cottrell, L., Griffin, R., Takami, A., Miyoshi, T., Hatakeyama, S., Shimono, A., Sun, J. Y., Zhang, Y. M., Dzepina, K., Kimmel, J. R., Sueper, D., Jayne, J. T., Herndon, S. C., Trimborn, A. M., Williams, L. R., Wood, E. C., Middlebrook, A. M., Kolb, C. E., Baltensperger, U., and Worsnop, D. R.: Evolution of Organic Aerosols in the Atmosphere, Science, 326, 1525-1529, https://doi.org/10.1126/science.1180353, 2009.

Joosten, H. and Clarke, D.: Wise Use of Mires and Peatlands - and Including Framework for Decision-Making, International Mire Conservation Group and International Peat Society, Saarijärven Offset Oy, Saarijärvi, Finland, 2002

Kirchstetter, T. W. and Thatcher, T. L.: Contribution of organic carbon to wood smoke particulate matter absorption of solar radiation, Atmos. Chem. Phys., 12, 6067-6072, https://doi.org/10.5194/acp-12-6067-2012, 2012.

Kirchstetter, T. W., Novakov, T., and Hobbs, P. V.: Evidence that the spectral dependence of light absorption by aerosols is affected by organic carbon, J. Geophys. Res.-Atmos., 109, 1-12, https://doi.org/10.1029/2004JD004999, 2004.

Kohlenberg, A. J., Turetsky, M. R., Thompson, D. K., Branfireun, B. A., and Mitchell, C. P. J.: Controls on boreal peat combustion and resulting emissions of carbon and mercury, Environ. Res. Lett., 13, 035005, https://doi.org/10.1088/1748-9326/aa9ea8, 2018.
Laskin, A., Laskin, J., and Nizkorodov, S. A.: Chemistry of Atmospheric Brown Carbon, Chem. Rev., 115, 4335-4382, https://doi.org/10.1021/cr5006167, 2015.

Legrand, M., Preunkert, S., Jourdain, B., Guilhermet, J., Faïn, X., Alekhina, I., and Petit, J. R.: Water-soluble organic carbon in snow and ice deposited at Alpine, Greenland, and Antarctic sites: a critical review of available data and their atmospheric relevance, Clim. Past, 9, 2195-2211, https://doi.org/10.5194/cp-92195-2013, 2013.

Lewis, K., Arnott, W. P., Moosmüller, H., and Wold, C. E.: Strong spectral variation of biomass smoke light absorption and single scattering albedo observed with a novel dual-wavelength photoacoustic instrument, J. Geophys. Res., 113, D16203, https://doi.org/10.1029/2007JD009699, 2008.

Lin, G., Penner, J. E., Flanner, M. G., Sillman, S., Xu, L., and Zhou, C.: Radiative forcing of organic aerosol in the atmosphere and on snow: Effects of SOA and brown carbon, J. Geophys. Res. Atmos., 119, 7453-7476, https://doi.org/10.1002/2013JD021186, 2014.

Linstrom, P. J. and Mallard, W. G.: NIST Standard Reference Database Number 69, edited by: Linstrom, P. J. and Mallard, W. G., NIST Chem. Webb., https://doi.org/10.18434/T4D303, 2018.

Lu, Z., Streets, D. G., Winijkul, E., Yan, F., Chen, Y., Bond, T. C., Feng, Y., Dubey, M. K., Liu, S., Pinto, J. P., and Carmichael, G. R.: Light absorption properties and radiative effects of primary organic aerosol emissions, Environ. Sci. Technol., 49, 48684877, https://doi.org/10.1021/acs.est.5b00211, 2015.

McConnell, J. R., Edwards, R., Kok, G. L., Flanner, M. G., Zender, C. S., Saltzman, E. S., Banta, J. R., Pasteris, D. R., Carter, M. M., and Kahl, J. D. W.: 20th-Century industrial black carbon emissions altered arctic climate forcing, Science, 317, 1381-1384, https://doi.org/10.1126/science.1144856, 2007.

McDaniel, M. and Zielinska, B.: Polycyclic Aromatic Hydrocarbons in the Snowpack and Surface Water in Blackwood Canyon, Lake Tahoe, CA, as Related to Snowmobile Activity, Polycycl. Aromat. Comp., 35, 102-119, https://doi.org/10.1080/10406638.2014.935449, 2015.

McNaughton, C. S., Clarke, A. D., Freitag, S., Kapustin, V. N., Kondo, Y., Moteki, N., Sahu, L., Takegawa, N., Schwarz, J. P., Spackman, J. R., Watts, L., Diskin, G., Podolske, J., Holloway, J. S., Wisthaler, A., Mikoviny, T., de Gouw, J., Warneke, C., Jimenez, J., Cubison, M., Howell, S. G., Middlebrook, A., Bahreini, R., Anderson, B. E., Winstead, E., Thornhill, K. L., Lack, D., Cozic, J., and Brock, C. A.: Absorbing aerosol in the troposphere of the Western Arctic during the 2008 ARCTAS/ARCPAC airborne field campaigns, Atmos. Chem. Phys., 11, 7561-7582, https://doi.org/10.5194/acp-117561-2011, 2011.

Meinander, O., Kazadzis, S., Arola, A., Riihelä, A., Räisänen, P., Kivi, R., Kontu, A., Kouznetsov, R., Sofiev, M., Svensson, J., Suokanerva, H., Aaltonen, V., Manninen, T., Roujean, J.-L., and Hautecoeur, O.: Spectral albedo of seasonal snow during intensive melt period at Sodankylä, beyond the Arctic Circle, Atmos. Chem. Phys., 13, 3793-3810, https://doi.org/10.5194/acp13-3793-2013, 2013.

Meyer, T. and Wania, F.: Organic contaminant amplification during snowmelt, Water Res., 42, 1847-1865, https://doi.org/10.1016/j.watres.2007.12.016, 2008. 
Mie, G.: Beiträge zur Optik trüber Medien, speziell kolloidaler Metallösungen, Ann. Phys., 330, 377-445, https://doi.org/10.1002/andp.19083300302, 1908.

Moosmüller, H. and Sorensen, C. M.: Single scattering albedo of homogeneous, spherical particles in the transition regime, J. Quant. Spectrosc. Ra., 219, 333-338, https://doi.org/10.1016/j.jqsrt.2018.08.015, 2018a.

Moosmüller, H. and Sorensen, C. M.: Small and large particle limits of single scattering albedo for homogeneous, spherical particles, J. Quant. Spectrosc. Ra., 204, 250-255, https://doi.org/10.1016/j.jqsrt.2017.09.029, 2018b.

Moosmüller, H. and Sorensen, C. M.: Erratum to "Small and large particle limits of single scattering albedo for homogeneous, spherical particles" [J. Quant. Spectrosc. Radiat. Transfer 204 (2018) 250-255], J. Quant. Spectrosc. Ra., 204, 2018-2019, https://doi.org/10.1016/j.jqsrt.2019.05.020, 2019.

Moosmüller, H., Chakrabarty, R. K., and Arnott, W. P.: Aerosol light absorption and its measurement: A review, J. Quant. Spectrosc. Ra., 110, 844-878, https://doi.org/10.1016/j.jqsrt.2009.02.035, 2009.

Moosmüller, H., Chakrabarty, R. K., Ehlers, K. M., and Arnott, W. P.: Absorption Ångström coefficient, brown carbon, and aerosols: basic concepts, bulk matter, and spherical particles, Atmos. Chem. Phys., 11, 1217-1225, https://doi.org/10.5194/acp11-1217-2011, 2011.

Moosmüller, H., Engelbrecht, J. P., Skiba, M., Frey, G., Chakrabarty, R. K., and Arnott, W. P.: Single scattering albedo of fine mineral dust aerosols controlled by iron concentration, J. Geophys. Res.-Atmos., 117, D11210, https://doi.org/10.1029/2011JD016909, 2012.

Oris, F., Asselin, H., Ali, A. A., Finsinger, W., and Bergeron, Y.: Effect of increased fire activity on global warming in the boreal forest, Environ. Rev., 22, 206-219, https://doi.org/10.1139/er-20130062, 2014.

Painter, T. H., Barrett, A. P., Landry, C. C., Neff, J. C., Cassidy, M. P., Lawrence, C. R., McBride, K. E., and Farmer, G. L.: Impact of disturbed desert soils on duration of mountain snow cover, Geophys. Res. Lett., 34, L12502, https://doi.org/10.1029/2007GL030284, 2007.

Painter, T. H., Seidel, F. C., Bryant, A. C., McKenzie Skiles, S., and Rittger, K.: Imaging spectroscopy of albedo and radiative forcing by light-absorbing impurities in mountain snow, J. Geophys. Res.-Atmos., 118, 9511-9523, https://doi.org/10.1002/jgrd.50520, 2013.

Patterson, E. M. and McMahon, C. K.: Absorption characteristics of forest fire particulate matter, Atmos. Environ., 18, 2541-2551, https://doi.org/10.1016/0004-6981(84)90027-1, 1984.

Peltoniemi, J. I., Gritsevich, M., Hakala, T., DagssonWaldhauserová, P., Arnalds, Ó., Anttila, K., Hannula, H.-R., Kivekäs, N., Lihavainen, H., Meinander, O., Svensson, J., Virkkula, A., and de Leeuw, G.: Soot on Snow experiment: bidirectional reflectance factor measurements of contaminated snow, The Cryosphere, 9, 2323-2337, https://doi.org/10.5194/tc9-2323-2015, 2015.

Potter, B. B. and Wimsatt, J. C.: USEPA method 415.3: Quantifying TOC, DOC, and SUVA, J. Am. Water Works Assoc., 104, E358E369, https://doi.org/10.5942/jawwa.2012.104.0086, 2012.
Pretsch, E., Bühlmann, P., and Affolter, C.: Structure Determination of Organic Compounds, Springer Berlin Heidelberg, Berlin, Heidelberg, 2000.

Qian, Y., Yasunari, T. J., Doherty, S. J., Flanner, M. G., Lau, W. K. M., Ming, J., Wang, H., Wang, M., Warren, S. G., and Zhang, R.: Light-absorbing particles in snow and ice: Measurement and modeling of climatic and hydrological impact, Adv. Atmos. Sci., 32, 64-91, https://doi.org/10.1007/s00376-014-0010-0, 2015.

Reid, J. S., Koppmann, R., Eck, T. F., and Eleuterio, D. P.: A review of biomass burning emissions part II: intensive physical properties of biomass burning particles, Atmos. Chem. Phys., 5, 799825, https://doi.org/10.5194/acp-5-799-2005, 2005.

Samburova, V., Szidat, S., Hueglin, C., Fisseha, R., Baltensperger, U., Zenobi, R., and Kalberer, M.: Seasonal variation of highmolecular-weight compounds in the water-soluble fraction of organic urban aerosols, J. Geophys. Res.-Atmos., 110, 1-9, https://doi.org/10.1029/2005JD005910, 2005.

Samburova, V., Connolly, J., Gyawali, M., Yatavelli, R. L. N., Watts, A. C., Chakrabarty, R. K., Zielinska, B., Moosmüller, H., and Khlystov, A.: Polycyclic aromatic hydrocarbons in biomass-burning emissions and their contribution to light absorption and aerosol toxicity, Sci. Total Environ., 568, 391-401, https://doi.org/10.1016/j.scitotenv.2016.06.026, 2016.

Satheesh, S. K. and Krishna Moorthy, K.: Radiative effects of natural aerosols: A review, Atmos. Environ., 39, 2089-2110, https://doi.org/10.1016/j.atmosenv.2004.12.029, 2005.

Schaepman-Strub, G., Schaepman, M. E., Painter, T. H., Dangel, S., and Martonchik, J. V.: Reflectance quantities in optical remote sensing-definitions and case studies, Remote Sens. Environ., 103, 27-42, https://doi.org/10.1016/j.rse.2006.03.002, 2006.

Sengupta, D., Samburova, V., Bhattarai, C., Kirillova, E., Mazzoleni, L., Iaukea-Lum, M., Watts, A., Moosmüller, H., and Khlystov, A.: Light absorption by polar and non-polar aerosol compounds from laboratory biomass combustion, Atmos. Chem. Phys., 18, 10849-10867, https://doi.org/10.5194/acp-18-108492018, 2018.

Skiles, S. M. and Painter, T. H.: Assessment of Radiative Forcing by Light-Absorbing Particles in Snow from In Situ Observations with Radiative Transfer Modeling, J. Hydrometeorol., 19, 13971409, https://doi.org/10.1175/JHM-D-18-0072.1, 2018.

Skiles, S. M., Painter, T. H., and Okin, G. S.: A method to retrieve the spectral complex refractive index and single scattering optical properties of dust deposited in mountain snow, J. Glaciol., 63, 133-147, https://doi.org/10.1017/jog.2016.126, 2017.

Skiles, S. M., Flanner, M., Cook, J. M., Dumont, M., and Painter, T. H.: Radiative forcing by light-absorbing particles in snow, Nat. Clim. Change, 8, 964-971, https://doi.org/10.1038/s41558-0180296-5, 2018.

Sokolik, I. N. and Toon, O. B.: Incorporation of mineralogical composition into models of the radiative properties of mineral aerosol from UV to IR wavelengths, J. Geophys. Res.-Atmos., 104, 9423-9444, https://doi.org/10.1029/1998JD200048, 1999.

Sorensen, C. M., Maughan, J. B., and Moosmüller, H.: Spherical particle absorption over a broad range of imaginary refractive index, J. Quant. Spectrosc. Ra., 226, 81-86, https://doi.org/10.1016/j.jqsrt.2019.01.011, 2019.

Sterle, K. M., McConnell, J. R., Dozier, J., Edwards, R., and Flanner, M. G.: Retention and radiative forcing of black carbon 
in eastern Sierra Nevada snow, The Cryosphere, 7, 365-374, https://doi.org/10.5194/tc-7-365-2013, 2013.

Stier, P., Seinfeld, J. H., Kinne, S., and Boucher, O.: Aerosol absorption and radiative forcing, Atmos. Chem. Phys., 7, 5237-5261, https://doi.org/10.5194/acp-7-5237-2007, 2007.

Stocker, T. F., Qin, D., Plattner, G.-K., Tignor, M., Allen, S. K., Boschung, J., Nauels, A., Xia, Y., Bex, V., and Midgley, P. M. (Eds.): IPCC, 2013: Summary for Policy Makers, in Climate Change 2013: The Physical Science Basis. Contribution of Working Group I to the Fifth Assessment Report of the Intergovernmental Panel on Climate Change, Cambridge University Press, Cambridge, United Kingdom and New York, NY, USA, 2013.

Strack, J. E., Pielke, R. A., and Liston, G. E.: Arctic tundra shrub invasion and soot deposition: Consequences for spring snowmelt and near-surface air temperatures, J. Geophys. Res.-Biogeo., 112, 1-12, https://doi.org/10.1029/2006JG000297, 2007.

Sumlin, B. J., Pandey, A., Walker, M. J., Pattison, R. S., Williams, B. J., and Chakrabarty, R. K.: Atmospheric Photooxidation Diminishes Light Absorption by Primary Brown Carbon Aerosol from Biomass Burning, Environ. Sci. Technol. Lett., 4, 540-545, https://doi.org/10.1021/acs.estlett.7b00393, 2017.

Sumlin, B. J., Oxford, C. R., Seo, B., Pattison, R. R., Williams, B. J., and Chakrabarty, R. K.: Density and Homogeneous Internal Composition of Primary Brown Carbon Aerosol, Environ. Sci. Technol., 52, 3982-3989, https://doi.org/10.1021/acs.est.8b00093, 2018a.

Sumlin, B. J., Heinson, Y. W., Shetty, N., Pandey, A., Pattison, R. S., Baker, S., Hao, W. M., and Chakrabarty, R. K.: UV-VisIR spectral complex refractive indices and optical properties of brown carbon aerosol from biomass burning, J. Quant. Spectrosc. Ra., 206, 392-398, https://doi.org/10.1016/j.jqsrt.2017.12.009, 2018b.

Sun, H., Biedermann, L., and Bond, T. C.: Color of brown carbon: A model for ultraviolet and visible light absorption by organic carbon aerosol, Geophys. Res. Lett., 34, L17813, https://doi.org/10.1029/2007GL029797, 2007.

Thomas, W. H. and Duval, B.: Sierra Nevada, California, U.S.A., Snow Algae: Snow Albedo Changes, Algal-Bacterial Interrelationships, and Ultraviolet Radiation Effects, Arctic Alpine Res., 27, 389-399, https://doi.org/10.2307/1552032, 1995.

Turetsky, M. R., Benscoter, B., Page, S., Rein, G., van der Werf, G. R., and Watts, A.: Global vulnerability of peatlands to fire and carbon loss, Nat. Geosci., 8, 11-14, https://doi.org/10.1038/ngeo2325, 2014.

Turquety, S., Logan, J. A., Jacob, D. J., Hudman, R. C., Leung, F. Y., Heald, C. L., Yantosca, R. M., Wu, S., Emmons, L. K., Edwards, D. P., and Sachse, G. W.: Inventory of boreal fire emissions for North America in 2004: Importance of peat burning and pyroconvective injection, J. Geophys. Res.-Atmos., 112, 113, https://doi.org/10.1029/2006JD007281, 2007.

Twardowski, M. S., Boss, E., Sullivan, J. M., and Donaghay, P. L.: Modeling the spectral shape of absorption by chromophoric dissolved organic matter, Mar. Chem., 89, 69-88, https://doi.org/10.1016/j.marchem.2004.02.008, 2004.

Waddington, E. D., Cunningham, J., and Harder, S. L.: The Effects Of Snow Ventilation on Chemical Concentrations, in: Chemical Exchange Between the Atmosphere and Polar Snow, 403-451, Springer Berlin Heidelberg, Berlin, Heidelberg, 1996.
Warren, S. G.: Optical properties of snow, Rev. Geophys., 20, 6789, https://doi.org/10.1029/RG020i001p00067, 1982.

Warren, S. G. and Wiscombe, W. J.: A Model for the Spectral Albedo of Snow. II: Snow Containing Atmospheric Aerosols, J. Atmos. Sci., 37, 2734-2745, https://doi.org/10.1175/15200469(1980)037<2734:AMFTSA>2.0.CO;2, 1980.

Warren, S. G., Roesler, C. S., Brandt, R. E., and Curran, M.: Green Icebergs Revisited, J. Geophys. Res.-Oceans, 124, 925938, https://doi.org/10.1029/2018JC014479, 2019.

Watts, A. C. and Kobziar, L. N.: Smoldering combustion and ground fires:, Fire Ecol., 9, 124-132, https://doi.org/10.4996/fireecology.0901124, 2013.

Wiscombe, W. J. and Warren, S. G.: A Model for the Spectral Albedo of Snow. I: Pure Snow, J. Atmos. Sci., 37, 2712-2733, https://doi.org/10.1175/1520 0469(1980)037<2712:AMFTSA>2.0.CO;2, 1980.

Wu, G. M., Cong, Z. Y., Kang, S. C., Kawamura, K., Fu, P. Q., Zhang, Y. L., Wan, X., Gao, S. P., and Liu, B.: Brown carbon in the cryosphere: Current knowledge and perspective, Adv. Clim. Chang. Res., 7, 82-89, https://doi.org/10.1016/j.accre.2016.06.002, 2016.

$\mathrm{Xu}$, J., Morris, P. J., Liu, J., and Holden, J.: PEATMAP: Refining estimates of global peatland distribution based on a meta-analysis, Catena, 160, 134-140, https://doi.org/10.1016/j.catena.2017.09.010, 2018.

Yacobi, Y. Z., Alberts, J. J., Takács, M., and McElvaine, M.: Absorption spectroscopy of colored dissolved organic carbon in Georgia (USA) rivers: the impact of molecular size distribution, J. Limnol., 62, 41-46, https://doi.org/10.4081/jlimnol.2003.41, 2003.

Yallop, M. L., Anesio, A. M., Perkins, R. G., Cook, J., Telling, J., Fagan, D., MacFarlane, J., Stibal, M., Barker, G., Bellas, C., Hodson, A., Tranter, M., Wadham, J., and Roberts, N. W.: Photophysiology and albedo-changing potential of the ice algal community on the surface of the Greenland ice sheet, ISME J., 6, 2302-2313, https://doi.org/10.1038/ismej.2012.107, 2012.

Yan, F., Kang, S., Li, C., Zhang, Y., Qin, X., Li, Y., Zhang, X., Hu, Z., Chen, P., Li, X., Qu, B., and Sillanpää, M.: Concentration, sources and light absorption characteristics of dissolved organic carbon on a medium-sized valley glacier, northern Tibetan Plateau, The Cryosphere, 10, 2611-2621, https://doi.org/10.5194/tc-10-2611-2016, 2016.

Yee, L. D., Kautzman, K. E., Loza, C. L., Schilling, K. A., Coggon, M. M., Chhabra, P. S., Chan, M. N., Chan, A. W. H., Hersey, S. P., Crounse, J. D., Wennberg, P. O., Flagan, R. C., and Seinfeld, J. H.: Secondary organic aerosol formation from biomass burning intermediates: phenol and methoxyphenols, Atmos. Chem. Phys., 13, 8019-8043, https://doi.org/10.5194/acp13-8019-2013, 2013.

Zhang, X. L., Wu, G. J., Zhang, C. L., Xu, T. L., and Zhou, Q. Q.: What is the real role of iron oxides in the optical properties of dust aerosols?, Atmos. Chem. Phys., 15, 12159-12177, https://doi.org/10.5194/acp-15-12159-2015, 2015.

Zhang, Y., Kang, S., Gao, T., Schmale, J., Liu, Y., Zhang, W., Guo, J., Du, W., Hu, Z., Cui, X., and Sillanpää, M.: Dissolved organic carbon in snow cover of the Chinese Altai Mountains, Central Asia: Concentrations, sources and lightabsorption properties, Sci. Total Environ., 647, 1385-1397, https://doi.org/10.1016/j.scitotenv.2018.07.417, 2019. 